\title{
Enhancing legume crop pollination and natural pest regulation for improved food security in changing African landscapes
}

Article

Accepted Version

Creative Commons: Attribution-Noncommercial-No Derivative Works 4.0

Otieno, M. ORCID: https://orcid.org/0000-0002-8509-3298, Steffan-Dewenter, I. ORCID: https://orcid.org/0000-0003-13593944, Potts, S. G. ORCID: https://orcid.org/0000-0002-2045980X, Kinuthia, W., Kasina, M. J. and Garratt, M. P. D. ORCID: https://orcid.org/0000-0002-0196-6013 (2020) Enhancing legume crop pollination and natural pest regulation for improved food security in changing African landscapes. Global Food Security, 26. 100394. ISSN 2211-9124 doi: https://doi.org/10.1016/j.gfs.2020.100394 Available at https://centaur.reading.ac.uk/92768/

It is advisable to refer to the publisher's version if you intend to cite from the work. See Guidance on citing.

Published version at: http://dx.doi.org/10.1016/j.gfs.2020.100394

To link to this article DOI: http://dx.doi.org/10.1016/j.gfs.2020.100394

Publisher: Elsevier

All outputs in CentAUR are protected by Intellectual Property Rights law, including copyright law. Copyright and IPR is retained by the creators or other copyright holders. Terms and conditions for use of this material are defined in the End User Agreement. 


\section{www.reading.ac.uk/centaur}

\section{CentAUR}

Central Archive at the University of Reading

Reading's research outputs online 


\section{$1 \quad$ Review paper}

2 Enhancing legume crop pollination and natural pest regulation for improved food security

3 in changing African landscapes

4 Otieno, Mark ${ }^{\mathrm{a}, \mathrm{e}^{*}}$ Steffan-Dewenter, Ingolf ${ }^{\mathrm{a}}$, Potts, G. Simon ${ }^{\mathrm{b}}$, Kinuthia, Wanja ${ }^{\mathrm{c}}$, Kasina, Muo

5 John $^{\mathrm{d}}$, Garratt, P.D. Michael ${ }^{\mathrm{b}}$

6 a* Department of Animal Ecology and Tropical Biology, Biocenter, University of Würzburg,

$7 \quad$ Würzburg, Germany; mmarkotieno@gmail.com

$8 \quad{ }^{\mathrm{b}}$ Centre for Agri-Environmental Research, School of Agriculture, Policy and Development,

$9 \quad$ University of Reading, Reading, RG6 6AR, $U K$

$10{ }^{c}$ National Museums of Kenya, Centre for Bee Biology and Pollination, P.O. Box 4065800100,

11 Nairobi, Kenya

$12{ }^{d}$ Kenya Agricultural and Livestock Research Organisation-Sericulture, P.O. Box 7816-01000

13 Thika, Kenya

$14{ }^{e}$ Department of Agricultural Resource Management, University of Embu, P.O. Box 6-60100,

15 Embu, Kenya

16 *Corresponding author

$17+$ denotes studies done outside the African continent but relevant in providing baseline for 18 understanding legume pollination and pest control. 
1

2

3

4

\section{|Review paper}

\section{Enhancing legume crop pollination and natural pest regulation for improved food security}

\section{in changing African landscapes}

\section{Abstract}

Legumes are important crops for food security, consumed by millions of people especially in Africa where they are an essential proteins source and provide key vitamins and minerals. Most legumes depend on insect pollination and natural pest regulation for sufficient yields, however, there is emerging evidence that yield gaps caused by lack of pollination and/or pest pressure may be common. Here we review the literature reporting on pollinators and natural enemies contributing to legume crop yields, and the impact of land-use change on the services provided by these beneficial organisms. We identify strategies for enhancing the benefits of pollination and natural pest control in legumes and propose policy and practice interventions for better utilization of pollinators and natural enemies in legume cropping systems in Africa.

Key words: Africa, ecosystem services, food security, legumes, natural pest enemies, pollination

\section{1) Introduction}

Legumes (Family Fabaceae, also referred to as Leguminosae) are a multipurpose crop and are consumed in both fresh and dry forms either directly as food or in various processed forms as animal feed or used as bio-energy crops (Merga and Haji, 2019; Snapp et al., 2019; Vanlauwe et al., 2019). Legumes (e.g. pigeon pea, groundnuts, cowpeas, and dry beans) are essential in the diets of millions of people across the world especially those in developing countries where they provide essential proteins, key vitamins, and minerals (Nedumaran et al., 2015). Legume consumption in sub-Saharan Africa is estimated to be approximately 4-6 kg/person per year 
1 (Nedumaran et al., 2015). These crops are a particularly important protein sources for vegans and

2 vegetarians as well as those with limited access to meat (Nedumaran et al., 2015; Ojiewo et al.,

3 2015; Bradbury et al., 2017 $)$. Furthermore, legumes also provide amino acids, fiber, minerals

4 and other nutrients for livestock (Gulzar and Minnaar, 2016). An increasing human population

5 has led to rising demand for legume based foods (Stagnari et al., 2017) with increases seen in

6 both North America and Europe where prices have also risen (Nedumaran et al., 2015). These

7 trends are set to continue (Islam et al., 2019) and a significant shift towards legume production

8 will be needed in the near future in order to match this increasing demand.

9 In Africa, legumes are important for food and nutritional security as well as being a revenue

10 source for small-holder farmers (Vanlauewe et al., 2019). These crops provide food, feed, and

11 fuel to many rural communities (Muoni et al., 2019), while farmers also benefit from the

12 enrichment of soil fertility and reduced erosion because of the legume's nitrogen-fixing abilities

13 and erosion control particularly provided by the dense root network of perennial legumes.

14 Legume production in Africa (as in the other parts of the world) has been increasing since the

15 year 2000 largely due to increasing groundnut, cowpea and common dry bean production (Fig.

16 1). Other legume crops (pigeon pea, broad beans, and green peas) have remained below 2 million

17 tons for 19 years (2000 - 2018) (Fig. 1 and Appendix 1). However, soybean production has been 18 increasing since 2010 (Fig. 1). 


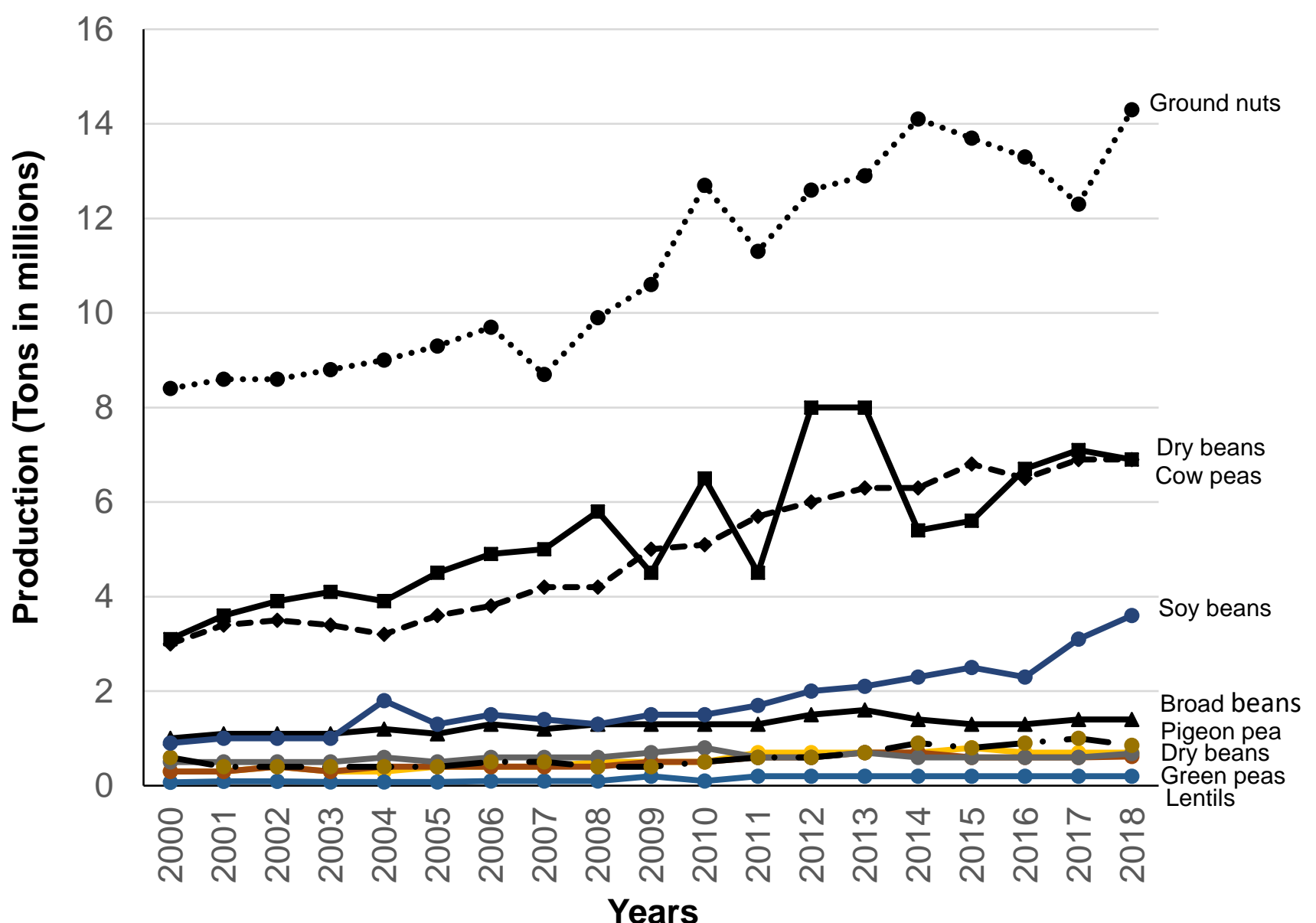

1

2

3

4

Figure 1: Trends in legume production by crop (millions of tons) in Africa from 2000 to 2017 (Source: FAOSTAT, 2020).

Despite being an important food security crop to many millions of rural people and smallholder farmers in Africa, legumes have not received as much attention as cereals with regards to research and development, particularly through plant breeding (Foyer et al., 2016). Based on recent production and yield trends, legumes are far below cereals, and yields are increasing at a much slower rate of $2.0 \%$ per annum (p.a.) compared to $3.8 \%$ p.a. for cereals (FAOSTAT, 2020) (Fig. 2). 


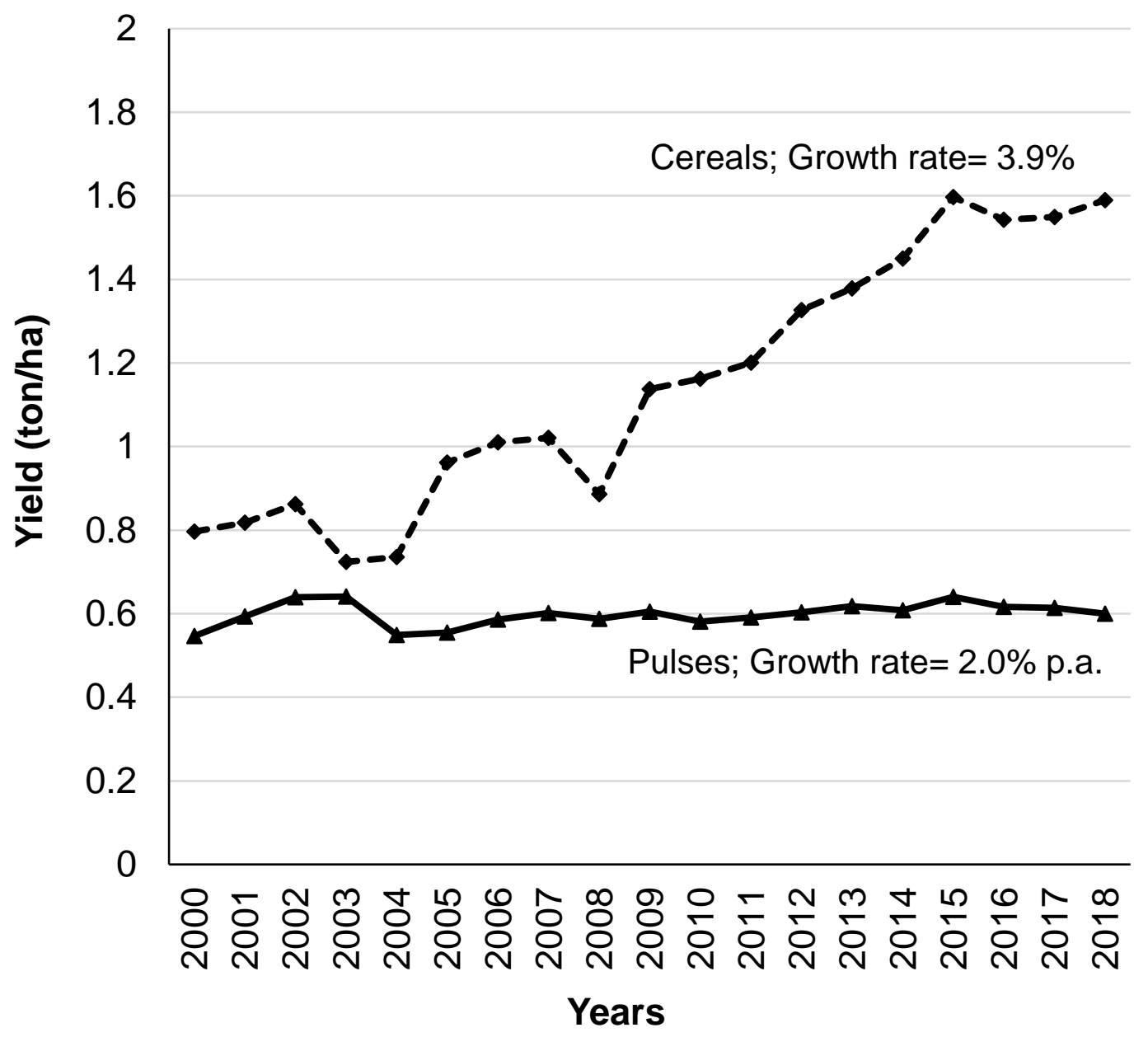

Figure 2: Yield/ha trends for cereal and pulse crops in Africa from 2000 to 2018 (Source: FAOSTAT, 2020)

Legume yield is partly dependent on arthropods, especially pollinating insects and natural enemies of pests (Suso et al., 2016; Delaplane and Mayer, 2000+; Grzywacz et al., 2014 ${ }^{+}$). This

7 includes important crops such as Bambara nuts (Vigna subterranea) (Kasina et al., 2009b), cow pea (Vigna unguiculata) (Pasquet et al., 2008), faba beans (Vicia faba) (Garratt et al., 2014+;

$9 \quad$ Nayak et al., 2015 ), pigeon peas (Cajanus cajan) (Otieno et al., 2011 and 2015) and forage legumes such as alfalfa (Medicago sativa), clover (Trifolium spp) and vetches (Vicia spp) (Snapp

11 et al., 2019). If legume production is going to continue to increase in Africa, it is essential to 
1 explore how pollinators and natural enemies can be used to support this increase in production

2 and keep pace with rising demand in changing African landscapes. This is particularly important

3 if yield is already constrained more by limited pollination or pest regulation than other crops in

4 Africa.

5 Globally, pollination is provided to legume crops by both managed (mainly honeybees) and wild

6 pollinators including the naturally occurring 'native bees' (Erickson et al 1978+, Benachour et

7 al., 2007+; Garratt et al., 2014). Likewise, in Africa honeybees are both managed (mainly for

8 honey production) and wild and both likely contribute to the pollination of legumes. In cropping

9 systems around the world, the abundance of native bees as crop pollinators is driven by farm

10 management practices and landscape context (Dainese et al., 2019 ${ }^{+}$). However, relatively few

11 studies on the factors driving pollination services to crops derive from Africa and yet yield

12 limitations linked to a shortage of insect pollination has been found in smallholder farming

13 systems, including those in Africa (Garibaldi et al., 2016 ${ }^{+}$).

14 Natural pest control is another important ecosystem service delivered to crops mostly by

15 invertebrates commonly referred to as natural enemies (den Belder et al., 2002 ${ }^{+}$). The presence of

16 natural enemies in crop fields can be an important factor in managing pest populations (Dainese

17 et al., $2019^{+}$) and similar to insect pollinators, farm management and local landscape context are

18 important determinants of natural enemy populations and the pest control services they provide

19 (Karp et al $2018^{+}$, Martin et al $2019^{+}$). Natural and semi-natural areas are used by natural

20 enemies as a refuge from undesirable on-farm conditions such as during pesticide sprays or they

21 provide alternative forage resources (Blitzer et al., 2012+; Balzan et al., 2014+; Ramsden et al.,

$222014^{+}$). Further, local crop rotation and crop diversity at the landscape scale can promote natural 
1 pest control (Schneider et al. $2015^{+}$, Redlich et al. $2018^{+}$), but comparable studies for Africa are

2 currently lacking.

3 In North America and Europe, the pollination requirements of many legume crops and the

4 contributions of pollinators to legume production have been established for example in soybeans

5 (Erickson et al., 1978 ${ }^{+}$) and field beans (Bartomeus et al., 2014+'; Garratt et al., 2014 ${ }^{+}$). Similarly,

6 pests and associated natural enemies are relatively well known for most temperate crops.

7 However, in developing countries, including those in Africa, knowledge of the pollination

8 requirements, pests and natural enemies of most legume crops is not well understood despite the

9 potential for using pollinators and natural enemies to safeguard legume production.

10 The objectives of this review with a focus on Africa are to; (i) examine the contributions of

11 pollination a nd natural pest control services to legume crop production (sections 2.1 and

12 3.1), (ii) highlight the current effects of agricultural intensification and land-use change on

13 pollinators and natural enemies and the ecosystem services they provide to legume crops in

14 Africa (sections 2.2 and 3.2), (iii) identify key gaps in our knowledge and propose avenues for

15 future research (section 4), and (iv) highlight regulations and policies that could be adopted for enhancing the benefits delivered by pollinators and natural enemies in legume cropping systems

17 (section 5).

18 We performed a systematic literature search using Web of Science and Web of Knowledge (ISI

19 Thompson-Reuters (www.webofknowledge.com) ) and Google Scholar

20 (https://scholar.google.com/) to identify studies that examined pollination or natural pest control

21 in legume crops in Africa. At the onset, we found no specific continent-wide studies on either

22 pollination or pest control in legumes. We, therefore, narrowed our search further to specific

23 regions and countries. We used search term combinations such as; "Legume" AND "pollinators" 
AND "East Africa" OR "Kenya" OR "Uganda" OR "Tanzania” for instance and repeated this for the other regions in the west, south, central, and north of Africa (Appendix 2). We repeated the search criteria for natural enemies by replacing "pollinators" with "natural enemies" OR "natural pest enemies" OR "biocontrol" OR "biological control". (An expanded list of all search terms is presented in Appendix 2). This criterion list produced only a limited number of studies so, we expanded our search by performing an extensive literature search of online databases and repositories of African academic and research institutions listed in the International African Institute's Digital Research Repositories for African studies

(https://www.internationalafricaninstitute.org/repositories) and used a combination of keywords relevant to this article, which yielded the 54 studies cited in Tables $1-3$ and elsewhere in this paper. Some studies outside Africa have been included in specific sections of this paper denoted by a superscript ${ }^{+}$sign. A decision was made to include these studies because they provide a critical baseline in understanding legume pollination and pest control.

\section{2) Pollination services underpinning legume crop production in Africa}

\subsection{Pollination of legume crops}

The effect of insect pollination on legume yield depends on whether the species or variety is selffertile or self-sterile. Self-fertile crops (e.g. soybeans and peanuts) generally do not require external vectors for pollination, however self-sterile crops (e.g. alfalfa) are up to $100 \%$ reliant on external agents for pollination. In some of the self-fertile species, however, it has been established that animal pollination can boost seed set when compared to purely self-pollinated plants e.g. $20-90 \%$ of pigeon pea fruit set is contributed by bees (Otieno et al., 2011; Pando et al 2011a; Fohouo at al. 2014; Mazi et al., 2014) and honeybees, carpenter bees, and leaf cutter bees enhance fruit set of cow pea by $10-100 \%$ (Fohouo et al., 2009; Kasina et al., 2009a; Ige et 
1 al., 2011; Musa et al., 2013; Stephanie et al., 2015; Wousla et al., 2019) (Table 1). It should be

noted, however, that for any crop type there are often major varietal differences in dependency on pollinators (Bishop et al., 2020).

The literature on crop pollination in Africa is generally limited (Gemmill-Herren et al., 2014), and studies focusing on legumes are particularly rare although research conducted outside the continent is relevant in some contexts. Overall, a very small proportion of crop-pollinator relationships have so far been characterized for legumes and even fewer studies have considered the community level and comparatively little applied work exists, either with regards to agriculture or conservation (Rodger et al., 2004). To date, a majority of pollination studies in Africa have focused on non-crop plant species investigating evolutionary relationships or breeding systems (Gemmill-Harren et al., 2014) and many studies which do exist are not traceable or accessible because they are locked in grey literature (Rodger et al., 2004, GemmillHarren et al., 2014).

Our review indicated that pollination studies in legume crops grown in Africa have generally focused on seven pulse crop species spread across the continent, namely; pigeon peas (Otieno et al., 2011; Pando et al., 2011a; Martins, 2013; Fohouo, 2014; Otieno et al., 2015), French beans (Valk et al., 2012; Masiga et al., 2014), cowpea (Pasquet et al., 2008; Fohouo et al., 2009; Kasina et al., 2009b; Ige et al., 2011; Wousla et al., 2019), runner beans (Pando et al., 2011b), bambara nuts (Kasina et al., 2009b), dry common beans (Kasina et al., 2009b), green grams (Kasina et al., 2009b) and, faba beans (Benachour et al., 2007) (see Table 1). Studies on pollination of other legume crops in Africa are not available. However, based on legume production data for Africa from the Food and Agricultural Organization, we included chickpeas, lentils, dry peas and 
1 soybeans in Table 1 and provided their pollination requirements based on studies done elsewhere

2 in the world.

\section{Pigeon pea (Cajanus cajan)}

4 Pigeon pea pollination has been studied more extensively than other legume crops (Table 1). The 5 consensus across all the studies considered is that in general insect pollinators increase yields. In

6 a study assessing the impact of a megachilid bee (Chalicodoma cincta) on pod and seed set of

7 pigeon peas, Pando et al., (2011a) found an increase in fruit set of between $19.65 \%$ and $96.72 \%$

8 on flowers visited by the bees compared to those not exposed to bee visits in a study from

9 Cameroon. Another study by Fohouo (et al., 2014) found carpenter bees increased pigeon pea

10 fruit set by $22.26 \%$. Martins (2013) reviewed case studies linking wild pollinators of crops

11 (including pigeon pea), natural habitat, and rural farmers and linked increased pigeon pea yield

12 to wild bee pollination, particularly by the carpenter and leafcutter bees in Mwanza, Tanzania.

13 The authors noted that the bees were extremely vulnerable to habitat degradation and loss.

14 Carpenter bees were also found to be important pollinators of pigeon pea in Kenya by Otieno et

15 al., (2015) where the abundance of bees was found to be correlated with pigeon pea fruit set.

\section{French beans (Phaseolus vulgaris)}

17 French beans, although largely thought to be self-fertile, were found to undergo outcrossing

18 aided by bees in Kenya, mostly dominated by honeybees and carpenter bees (Table 1) (Masiga et 19 al., 2014). Potential pollination deficits in this crop among small-scale farms was also found and 20 associated with proximity to natural habitats. Bean yield was also significantly correlated with 21 the mean abundance of carpenter bees.

\section{Cowpea (Vigna unguiculata)}


1 A study by Fohouo et al., (2009) investigating the foraging behavior of pollinators and

2 pollination of cowpea by Apis mellifera adansonii found the number of seeds per pod to be

3 significantly greater in openly pollinated flowers (62\%) when compared to those protected from

4 insects (48\%), mainly due to carpenter bees, leafcutter bees and honeybees (Table 1). Wousla et

5 al., (2019) also found that bees increased seed set in cowpea by between $1-10 \%$ in Kenya. This

6 was mainly attributed to leafcutter (Megachile spp.) and carpenter bees (Xylocopa spp.).

\section{Faba beans}

8 An increase in faba bean yield was associated with insect floral visitors. A study by Benachour et

9 al., (2007) in Algeria recorded that plants visited by insects produced more pods per plant, more

10 seeds per pod, and the seeds were heavier and of better shape than the plants receiving no bee 11 visits.

\section{Runner beans}

13 A study on foraging and behavior of carpenter bees on runner bean flowers in Cameroon 14 established a pollination deficit (Pando et al., 2011b). This study found a $25.8 \%$ increase in fruit 15 set following floral visitation by Xylocopa calens.

\section{Bambara nuts}

17 This crop was found to benefit from insect pollinators with a dependency ratio of 0.61 (Kasina et 18 al., 2009b). Here, dependency ratio reflects the contribution of pollination to food production and 19 corresponds to the quantitative relative loss of agricultural production that would be induced by 20 the disappearance of pollinators (Klein et al., 2007; Jacquemin et al., 2017).

\section{Green grams}


1 Insect pollinators increased the number of seeds per pod of green grams by $37.56 \%$ and seed

2 weight by $90.63 \%$ (Kasina et al., 2009b). 
$1 \quad$ Table 1: Summary of pollinators key to legume crop pollination in Africa

\begin{tabular}{|c|c|c|c|c|c|c|c|c|c|c|}
\hline & \multicolumn{10}{|c|}{ Crop } \\
\hline$\downarrow$ Pollinator & $\begin{array}{l}\text { Bean plants } \\
\text { (Phaseolus } \\
\text { vulgaris) - } \\
\text { French } \\
\text { beans, dry } \\
\text { beans green } \\
\text { beans }\end{array}$ & $\begin{array}{l}\text { Faba } \\
\text { beans } \\
\text { (Vicia } \\
\text { faba) }\end{array}$ & $\begin{array}{l}\text { Chick peas } \\
\text { (Cicer } \\
\text { arietinum) }\end{array}$ & $\begin{array}{l}\text { Cow peas } \\
\text { (Vigna } \\
\text { unguiculat } \\
\text { a) }\end{array}$ & $\begin{array}{l}\begin{array}{l}\text { Lentils } \\
\text { (Lens } \\
\text { culinaris) }\end{array}\end{array}$ & $\begin{array}{l}\text { Dry } \\
\text { peas } \\
\text { Pisum } \\
\text { sativum }\end{array}$ & $\begin{array}{l}\text { Pigeon } \\
\text { pea } \\
\text { (Cajanus } \\
\text { cajan) }\end{array}$ & $\begin{array}{l}\text { Soy } \\
\text { bean } \\
\text { (Glycine } \\
\text { max })\end{array}$ & $\begin{array}{l}\text { Peanut/groun } \\
\text { d nut (Vigna } \\
\text { subterranea) }\end{array}$ & $\begin{array}{l}\text { Runner } \\
\text { beans } \\
\text { (Phaseol } \\
\text { us } \\
\text { coccineu } \\
\text { s) }\end{array}$ \\
\hline $\begin{array}{l}\text { Dependence of } \\
\text { legumes on insect } \\
\text { pollination }\end{array}$ & $<30 \%$ & $<30 \%$ & $<30 \%$ & $30-70 \%$ & $<30 \%$ & $<30 \%$ & $<30 \%$ & $<30 \%$ & $<30 \%$ & $<30 \%$ \\
\hline $\begin{array}{l}\text { Honey bees } \\
\text { (Apis mellifera) }\end{array}$ & $50-60 \%$ & Yes & Yes & $10-70 \%$ & & & & $20 \%$ & 10 & Yes \\
\hline $\begin{array}{l}\text { Carpenter bees } \\
\text { (Xylocopa spp.) }\end{array}$ & $20-60 \%$ & & & $70-95 \%$ & & & $20 \%$ & 10 & & \\
\hline $\begin{array}{l}\text { Leaf cutter bees } \\
\text { (Megachilids) }\end{array}$ & Yes & & & $30-100 \%$ & & & $20-90 \%$ & & & \\
\hline $\begin{array}{l}\text { Halictid bees } \\
\text { (Lipotriches) }\end{array}$ & Yes & Yes & & & & & Yes & & & \\
\hline $\begin{array}{l}\text { Digger bees } \\
\text { (Anthrophorids } \\
\text { and Amegillas) }\end{array}$ & & Yes & Yes & & & & Yes & & & \\
\hline Ceratina & & & & & & & Yes & & & \\
\hline Stingless bees & & & & & & & Yes & & & \\
\hline Colletes & Yes & & & & & & & & & \\
\hline Bumble bees & & Yes & & $<1 \%$ & & & & & & Yes \\
\hline Eucera & & Yes & & & & & & & & \\
\hline $\begin{array}{l}\text { Flies (Syrphid and } \\
\text { Calliphorid) and } \\
\text { other fly } \\
\text { pollinators) }\end{array}$ & & Yes & Yes & & & & Yes & & & \\
\hline Beetles & & Yes & & & & & & & & \\
\hline References & $\begin{array}{l}\text { Roger et al, } \\
\text { 2004; Kasina } \\
\text { et al., 2009b; } \\
\text { Douka et al, } \\
\text { 2013; Douka } \\
\text { et al., 2017; } \\
\text { Masiga et. al, } \\
\text { 2014, } \\
\text { Fohouo et } \\
\text { al., } 2014\end{array}$ & 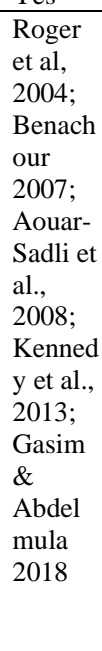 & $\begin{array}{l}\text { Latif et al., } \\
2019\end{array}$ & $\begin{array}{l}\text { Roger et al, } \\
2004 ; \\
\text { Pasquet at } \\
\text { al 2008; } \\
\text { Asiwe } \\
2009 ; \\
\text { Fatokun } \\
2002 \\
\text { Fohouo et } \\
\text { al., 2009; } \\
\text { Kasina et } \\
\text { al., 2009b; } \\
\text { Ige et al., } \\
2011 ; \\
\text { Musa et al., } \\
2013 ; \\
\text { Stephanie } \\
\text { et al., 2015; } \\
\text { Wousla et } \\
\text { al., 2019 }\end{array}$ & $\begin{array}{l}\text { Hornebur } \\
\text { g } 2006\end{array}$ & $\begin{array}{l}\text { Naeem } \\
\text { et al., } \\
2018\end{array}$ & $\begin{array}{l}\text { Roubik } \\
\text {,1995; } \\
\text { Roger et } \\
\text { al, 2004; } \\
\text { Otieno et } \\
\text { al., 2011; } \\
\text { Pando et } \\
\text { al 2011a; } \\
\text { Fohouo at } \\
\text { al. 2014; } \\
\text { Mazi et } \\
\text { al., 2014; } \\
\text { Otieno et } \\
\text { al 2015 }\end{array}$ & $\begin{array}{l}\text { de } \\
\text { Milfont } \\
\text { et al., } \\
2013 ; \\
\text { Blettler } \\
\text { et al., } \\
2018\end{array}$ & $\begin{array}{l}\text { Roubik ,1995; } \\
\text { Kasina et al., } \\
\text { 2009b }\end{array}$ & $\begin{array}{l}\text { Pando et } \\
\text { al., } \\
2011 \mathrm{~b}\end{array}$ \\
\hline
\end{tabular}

Note: Percentages given represent the amount of fruits set by corresponding pollinators (shown in column 1) on

3 legumes crops in Africa as reported in the literature. The percentages are rounded to the nearest $10 \%$. "Yes" denotes

4 that visitation to flowers of legumes by these insects was frequently recorded but their contribution to pollination 5 was not quantified. Full references to the citations are provided in Appendix 3a. 
1

\subsection{Impacts of agricultural intensification and land-use change on pollination services to}

\section{legume crops in Africa}

On a global scale agricultural intensification negatively affects pollinators by reducing nesting and forage resources as well as by increasing exposure to agrochemicals (Deguines et al., 2014;

Potts et al., 2016; Cairns et al., 2017) and Africa is no exception. For example, land-use change in Kenya, particularly through agricultural expansion, has contributed to habitat loss, environmental degradation, and land fragmentation, disrupting pollinator networks that are important in supporting and sustaining biological functions (Mwangi et al., 2012). Similarly, high usage of pesticides, herbicides, and fertilizers are exposing pollinators to further risk (Guenat et al., 2019).

Otieno et al., (2015) investigated the effects of agricultural intensification on pollinator guilds and found negative effects of insecticides on bee abundance and functional guilds when used on pigeon pea fields. This study also found a positive relationship between bee abundance and habitat complexity, characterized by small-holder farms interspersed with semi-natural habitats producing mosaics of heterogeneous habitats across the landscape. Pesticide use was also found to be a key negative predictor of pollinator abundance and richness, although by contrast the use of fertilizers significantly increased pollinator abundance. In another study, pesticides were also found to impact honeybee colonies by weakening their potential for crop pollination (Muli et al., 2014). This may be a result of pesticides impairing the bees' ability to learn floral associations and hence taking longer to find and pollinate flowers (Siviter et al. 2018). The extent to which this impacts legume crops reliant on honeybees is unknown. Masiga et al., (2014), while studying pollination deficits in French beans in Kenya, found that natural areas adjacent to crop 
1 fields were important for pollination service delivery and advocated area-wide habitat

2 management to support carpenter bees which are key pollinators of French beans.

\section{3) The role of natural enemies of pests in legume crop production in Africa}

\section{$4 \quad 3.1$ Natural enemies of legume crop pests} and large scale farming systems in Africa. Our review showed that legume crops suffer a multitude of pests affecting various parts of the plant and can cause significant losses to yield including up to $100 \%$ yield losses in some cases (Table 2).

Table 2: summary of pests of legume crops and associated yield losses in Africa

\begin{tabular}{|c|c|c|c|c|c|c|c|c|c|c|}
\hline $\begin{array}{l}\text { Common pest } \\
\text { orders }\end{array}$ & $\begin{array}{l}\text { Bean plants } \\
\text { (Phaseolus } \\
\text { vulgaris) }\end{array}$ & $\begin{array}{l}\text { Broad } \\
\text { beans } \\
\text { (Vicia faba) }\end{array}$ & $\begin{array}{l}\text { Chick } \\
\text { peas } \\
\text { (Cicer } \\
\text { arietinum) }\end{array}$ & $\begin{array}{l}\text { Cow peas } \\
\text { (Vigna } \\
\text { unguiculata) }\end{array}$ & $\begin{array}{l}\text { Pigeon } \\
\text { peas } \\
(\text { Vicia } \\
\text { faba })\end{array}$ & $\begin{array}{l}\text { Lentils } \\
\text { (Lens } \\
\text { culinaris } \\
\text { ) }\end{array}$ & $\begin{array}{l}\text { Dry peas } \\
\text { (Pisum } \\
\text { sativum) }\end{array}$ & $\begin{array}{l}\text { Peanut/gr } \\
\text { ound nut } \\
\text { (Vigna } \\
\text { subterrane } \\
\text { a) }\end{array}$ & $\begin{array}{l}\text { Runner } \\
\text { beans } \\
\text { (Phaseolu } \\
\text { s } \\
\text { coccineus } \\
\text { ) }\end{array}$ & $\begin{array}{l}\text { Soy bean } \\
\text { (Glycine } \\
\text { max) }\end{array}$ \\
\hline $\begin{array}{l}\text { Percentage yield } \\
\text { loss due to pests }\end{array}$ & $100 \%$ & $10-70 \%$ & $30-100 \%$ & $90-100 \%$ & $10-70 \%$ & $\infty$ & $80 \%$ & $70 \%$ & $\infty$ & $20-40 \%$ \\
\hline Isoptera & RO,LE & & ST & RO,LE & ST & & & $\mathrm{RO}, \mathrm{ST}$ & & \\
\hline Orthoptera & LE & LE & LE & LE & LE & & & & & LE \\
\hline Coleoptera & LE,FL,PO & LE,FL,PO & & $\begin{array}{l}\text { RO,LE,FL,P } \\
\mathrm{O}, \mathrm{SE}\end{array}$ & $\begin{array}{l}\text { LE,FL,PO } \\
\text {,SE }\end{array}$ & $\begin{array}{l}\text { RO, LE, } \\
\text { SE }\end{array}$ & RO, PO & LE & LE,PO & $\begin{array}{l}\text { LE, FL, } \\
\text { PO }\end{array}$ \\
\hline Hymenoptera & LE & & & LE & & & & & & LE, PO \\
\hline Thysanoptera & FL,PO & FL & & FL & LE, FL & $\begin{array}{l}\text { LE, FL, } \\
\text { PO }\end{array}$ & FL & & LE,FL & \\
\hline Lepidoptera & FL,PO & & $\begin{array}{l}\text { ST, } \\
\text { LE,POO }\end{array}$ & ST,FL,P,SE & ST,F,P,SE & $\mathrm{PO}, \mathrm{SE}$ & $\mathrm{PO}$ & $\mathrm{RO}$ & LE, FL & LE,PO \\
\hline Hemiptera & LE,FL,PO & LE,FL & LE & ST, LE,FL,P & LE,FL,PO & $\begin{array}{l}\text { RO, } \\
\text { LE,FL,P } \\
\text { O }\end{array}$ & LE & LE & LE,PO & $\begin{array}{l}\text { LE, PO, } \\
\text { SE }\end{array}$ \\
\hline Diptera & LE,FL,PO & & LE & LE,FL,PO & LE,FL,PO & LE & ST,LE & & & RO, ST \\
\hline References & $\begin{array}{l}\text { Abate and } \\
\text { Ampofo 1996; } \\
\text { Mwanauta et al., } \\
\text { 2015; Ochilo and } \\
\text { Nyamasyo 2011; } \\
\text { Ojwang' et al., } \\
2010\end{array}$ & $\begin{array}{l}\text { Hansen et } \\
\text { al., 2008; } \\
\text { Duan et al., } \\
2014 ; \\
\text { Stoddard } \\
2010\end{array}$ & $\begin{array}{l}\text { Latif et } \\
\text { al., } 2019\end{array}$ & $\begin{array}{l}\text { Karungi et } \\
\text { al., 2000; } \\
\text { Oyewale, } \\
\text { and Bamaiyi } \\
2013\end{array}$ & $\begin{array}{l}\text { Dialoke et } \\
\text { al., 2010; } \\
\text { Minja et } \\
\text { al., 1999; } \\
\text { Minja et } \\
\text { al., } 1999\end{array}$ & $\begin{array}{l}\text { Stevenso } \\
\text { n et al., } \\
2007\end{array}$ & $\begin{array}{l}\text { Ali et al } \\
2009\end{array}$ & $\begin{array}{l}\text { Mkandaw } \\
\text { ire et al., } \\
\text { 2007, } \\
\text { Dike } 1997\end{array}$ & $\begin{array}{l}\text { Biddle } \\
\text { and } \\
\text { Cattlin } \\
2007\end{array}$ & $\begin{array}{l}\text { Hartman } \\
\text { et al., } \\
2011 \text {; } \\
\text { Abudula } \\
\text { i et al., } \\
2012\end{array}$ \\
\hline
\end{tabular}

Note: the damaged plant parts are denoted by $\mathrm{RO}=$ Root, $\mathrm{FL}=$ flower, $\mathrm{PO}=$ pod, $\mathrm{SE}=$ seed, $\mathrm{ST}=\mathrm{Stem}$ and $\mathrm{LE}=$ leaf. $\infty$ denotes that yield loss attributed to pests for a particular crop was not reported. Full references to citations are provided in Appendix 3b.

Pest suppression by natural enemies has been recognized as an important regulating ecosystem service that can offer an environmentally benign solution to pest problems (Snyder, 2019+). 
1 Furthermore, interest in the use of natural enemies in Integrated Pest Management (IPM)

2 programs including legume cropping systems has grown in recent years, including in Africa

3 (Pretty and Bharucha, 2015).

4 In legume cropping systems, predators of insect pests include; spiders (Araneae), true bugs

5 (Hemiptera), ground beetles (Carabidae; Coleoptera), rove beetles (Staphylinidae; Coleoptera),

6 ladybird beetles (Coccinelidae; Coleoptera), praying mantis (Mantodea), lacewings (Neuroptera),

7 earwigs (Dermaptera), and hoverfly larvae (Syrphidae; Diptera) (Abtew et al., 2016; Brévault

8 and Clouvel, 2019). Parasitoids are also important natural enemies of some pests in Africa

9 (Mkenda et al., 2019a,b\&c) (Table 3).

Table 3. Summary of natural enemies and the pests they can help control in legume crops in

11 Africa

\begin{tabular}{|c|c|c|c|c|c|c|c|c|c|}
\hline & \multicolumn{8}{|c|}{ Pests - Orders } & \multirow[b]{2}{*}{ References } \\
\hline $\begin{array}{c}\text { Natural } \\
\text { enemies } \\
- \\
\text { Orders }\end{array}$ & Trombidiformes & Hemiptera & Lepidoptera & Thysanoptera & Hymenoptera & Diptera & Coleoptera & Orthoptera & \\
\hline Hemiptera & $\sqrt{ }$ & $\sqrt{ }$ & $\sqrt{ }$ & & & & & & $\begin{array}{l}\text { Lee and Landis, } \\
\text { 2001; Stewart et } \\
\text { al, 2007; } \\
\text { Javahery, 2013; }\end{array}$ \\
\hline Diptera & $\sqrt{ }$ & $\sqrt{ }$ & $\sqrt{ }$ & & & $\sqrt{ }$ & $\sqrt{ }$ & $\sqrt{ }$ & $\begin{array}{l}\text { Stewart et al, } \\
\text { 2007; Mahr et } \\
\text { al., 2008; } \\
\text { Ndakidemi et } \\
\text { al., 2016; } \\
\text { Pesticide Action } \\
\text { Network (PAN) } \\
\text { (2014) }\end{array}$ \\
\hline Coleoptera & $\sqrt{ }$ & $\sqrt{ }$ & $\sqrt{ }$ & $\sqrt{ }$ & $\sqrt{ }$ & $\sqrt{ }$ & & & $\begin{array}{l}\text { Chin and Brown } \\
\text { 2010; Lee and } \\
\text { Landis, } 2001\end{array}$ \\
\hline Neuroptera & $\sqrt{ }$ & $\sqrt{ }$ & & & & & & & $\begin{array}{l}\text { Lee and Landis, } \\
2001\end{array}$ \\
\hline Araneae & & $\sqrt{ }$ & $\sqrt{ }$ & & & $\sqrt{ }$ & & & $\begin{array}{l}\text { Ndakidemi et } \\
\text { al., } 2016\end{array}$ \\
\hline Hymenoptera & & $\sqrt{ }$ & $\sqrt{ }$ & & & $\sqrt{ }$ & & & $\begin{array}{l}\text { Ndakidemi et } \\
\text { al., } 2016\end{array}$ \\
\hline
\end{tabular}

Note: Full references to citations are provided in Appendix 3c.

14 In Africa, a limited understanding of the potential of natural enemies in pest control exists. In

15 East Africa, for instance, legumes are grown and consumed by millions of people and pests

16 remain one of the key challenges in the production process, yet the use of natural enemies to 
1 mitigate this challenge is limited (Belmain et al., 2013). Some studies however do demonstrate

2 the potential benefits of natural enemies. A review by Ndakidemi et al., (2016) found natural

3 enemies and pollinators within legume fields to play a key role in ensuring sustainable

4 production, especially in smallholder farms. Furthermore, Mkenda et al., (2019b\&c) identified

5 parasitoids and hyperparasitoids of aphids (Aphis fabae) on bean plants (Phaseolus vulgaris) and

6 proposed interventions to improve landscapes by adopting farming practices that can augment

7 the populations of the most common parasitoid, Aphidius colemani, to enhance pest control.

$8 \quad 3.2$ Impacts of agricultural intensification and land-use change on natural enemies in

$9 \quad$ legume crops in Africa

10 Changing land-use and farm management practices caused by agricultural expansion and

11 intensification to match the needs of a fast-growing population in Africa has resulted in the loss

12 of natural habitats in tandem with a decline in overall biodiversity (Tscharntke et al., 2005

13 Lamarque et al., 2011+; Belmain et al., 2013). The human population in Africa has almost

14 doubled since 2000 and is projected to be 2.4 billion people, compared to the current 1.3 billion,

15 by the year 2050 (United Nations, 2019). This could potentially result in drastic land-use change

16 leading to declines in indigenous plant species, which support beneficial native arthropod

17 species. This increase in population in tandem with increasing pulse legume production

18 (although with a slight decline between 2015 and 2017) (Fig. 3) is likely to cause increased

19 pressure on remaining natural or near-natural habitats, exacerbating the problems facing natural

20 enemies if no mitigation measures are put in place to safeguard the existence of these beneficial

21 organisms. 


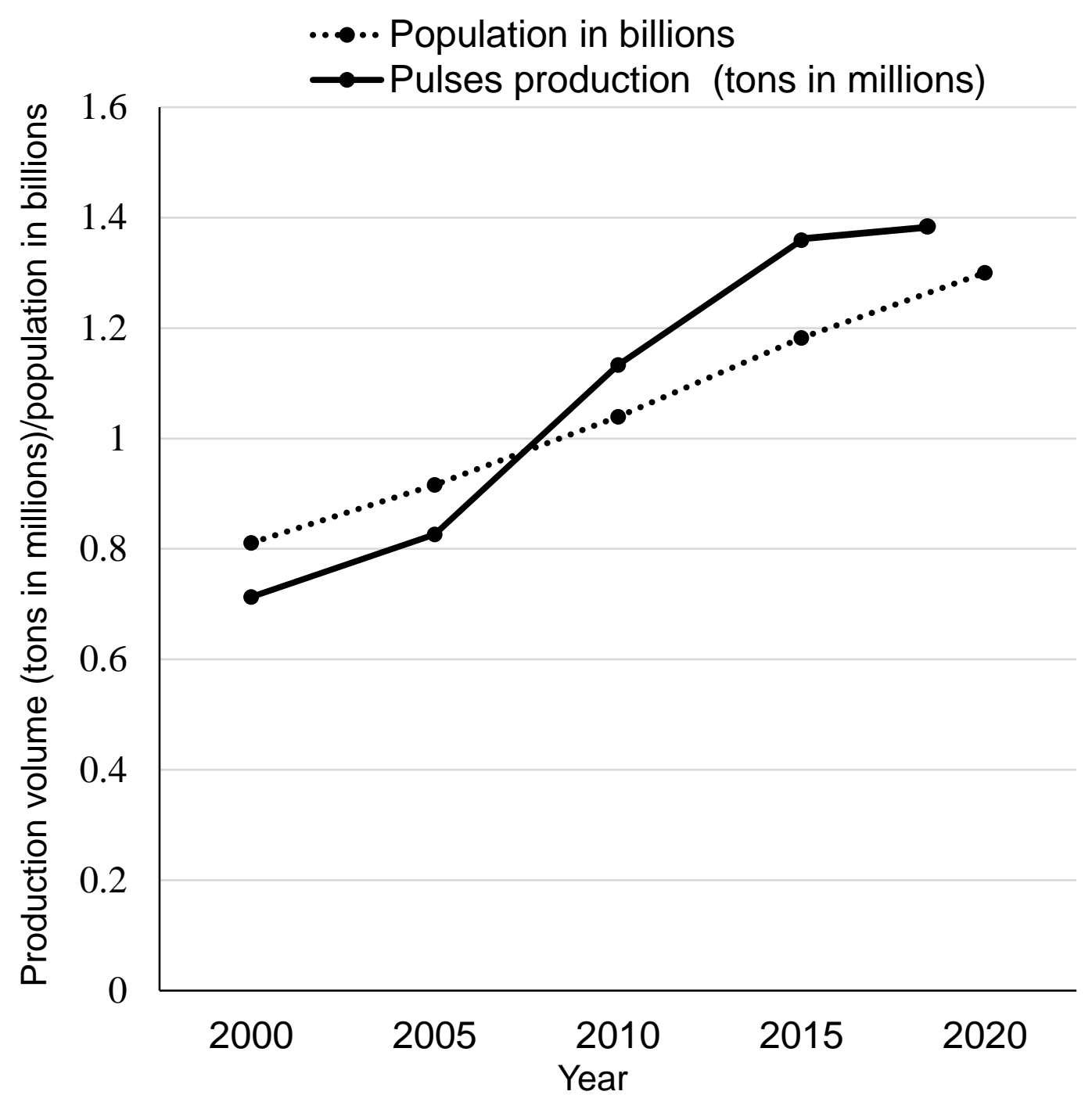

Figure 3: Trends in legume production (millions of tons) and population growth (billions of people) in Africa from 2000 to 2020 (Source: FAOSTAT, 2020 and World Population Prospects (2017 Revision) - United Nations population estimates and projections 2019). Note. Legume production data was only available up to 2018 by the time of this review. 
1 Agricultural intensification has resulted in considerable simplification of cropping systems in

terms of the diversity of crop species grown and management practices used in agricultural landscapes (Keating et al., 2013 ${ }^{+}$). For example, it was once common practice to intercrop maize, beans and pumpkins in small-holdings in Africa, providing all-year on-farm nutritious food, however such practices are declining (Pleasant, 2016). This agricultural simplification can result in the loss of natural enemy species which are generally supported by diverse discontinuous systems, thus weakening the ability of these beneficial organisms to suppress pest species, e.g. aphids (Zhao et al., 2015 ${ }^{+}$. As a result, pests can multiply in the absence of their natural enemies prompting farmers to adopt alternative strategies such as increasing the dosage and/or strength of pesticides resulting in reduced potential for natural pest control (Krauss et al. 2011) and associated environmental risks (Bon et al., 2014). Studies on other crops found that keeping some natural habitats in the landscape benefited natural enemies e.g. Kebede et al., (2018) and such approaches could be taken in legume cropping systems.

While there is generally only a limited body of literature on legume pollinators and natural enemies of pests in Africa, particularly those from which to deduce trends in the delivery of pollination and pest regulation services to legume crops, our review confirms the existence of three main patterns consistent with global trends, namely; (i) pollinators can significantly increase legume crop yields, and (ii) a diverse array of pests threaten legume yields but natural enemies can control these pests, but (iii) increasing agricultural intensification and human population growth has led to loss of near natural habitats on which pollinator and natural enemy communities rely and reduced crop diversity at local and landscape scales has put pressure on their populations and the services they provide. 


\section{4) Current knowledge gaps and avenues for future research}

3 Studies on the pollination requirements of key legume crops (including different varieties) and

4 how this varies between farming system, landscape and geographic regions are needed. To do

5 this, the use of available tools for the assessment of ecosystem services such as FAO's protocol

6 for assessing pollination deficits (Vaissière et al., 2011+) and the Toolkit for Ecosystem Service

7 Site-based Assessment (TESSA) (Peh et al., 2013+) can be employed. These protocols involve

8 pollinator exclusion and supplementary pollination techniques which has been effectively

9 employed in many crops and systems to identify levels of crop dependence and potential deficits and opportunities to increase yield through the management of pollinators (Garibaldi et al 2016).

Such research takes time and resources, but it could be targeted at those crops and varieties where evidence is lacking or that are of particularly high value. Furthermore, to increase geographical coverage or help with targeting management interventions, methods evaluating pollination could be implemented by farmers themselves (Garratt et al., 2019+).

Identifying individual invertebrate species or elements of the invertebrate community that are making the most important contributions to pollination based on abundance and effectiveness is also necessary to inform effective conservation and biodiversity management. The contribution of pollinators can be estimated by directly comparing the effectiveness of individual species to different crops in controlled experiments (Garratt et al., 2014+) or by considering species and community traits (Garabaldi et al., 2015+, Greenop et al., 2018+, Woodcock et al., 2019+) to identify species or groups of species with a key functional role in African legume production systems. 
1 Finally, there is also a need to study the regional and geographical distribution of legume

2 pollinators to help understand the impacts of possible drivers effecting pollinator populations

3 including land-use change, anthropogenic disturbance and climate change (Kerr et al. 2015;

$4 \quad$ Woodcock et al. 2016; Peters et al. 2019). Regional studies in Kenya have shown that some bee

5 species have narrower ecological niches - in terms of activity, host preference and interspecific

6 interactions and are therefore more sensitive to changes than generalist species e.g. honey bees

7 (see Otieno et al. 2015). A better understanding of legume pollinator traits through targeted

8 research will help predict the vulnerability of different pollinator species to various threats.

$9 \quad$ Natural enemies of pests

10 Studies establishing the role of natural enemies in controlling key pests in legume crops and

11 identifying trade-offs in using these organisms compared to chemical pesticides are needed.

12 These studies could, for instance, determine optimal application strategies (e.g. by pesticides)

13 that avoid unnecessary harm to predatory arthropods e.g. spiders, hoverfly larvae, ladybirds and

14 parasitoids. It is important to establish accurate economic thresholds for pests on legume crops

15 so that only selective pesticides are applied when necessary as part of an IPM strategy (Gentz et

16 al., 2010). Importantly, organic management, mixed cropping and new pest control approaches

17 such as push-pull systems require experimental testing and tailoring to legume crops but

18 represent huge potential for more sustainable farmland management in Africa (Hassanali et. al.

19 2008; Eyhorn et al., 2019).

20 Ecological intensification

21 Ecological intensification (EI) aims at increasing crop productivity by enhancing biodiversity

22 and associated ecosystem services while minimizing the use of synthetic inputs and cropland

23 expansion (Franke et al., 2018 ${ }^{+}$; Garibaldi et al., 2019 ${ }^{+}$). This practice presents a viable strategy 
1 for promoting beneficial insects important for legume crop production in Africa but currently

there is a lack of evidence for the potential of EI and effective tools for its implementation.

In the advent of habitat loss and land degradation leading to low habitat quality (Kennedy et al., $2013^{+}$; Ferreira et al., 2015+; Nemésio et al., 2016 ${ }^{+}$), community stability and processes such as pollination and natural pest regulation are weakened and networks destroyed (Kovács-

\section{Hostyánszki et al., $2017^{+}$). With these foregoing impacts, the employment of EI practices that} either restore or maintain semi-natural and natural habitats achieved through effective habitat management or establishment of boundary features, fallows, etc. can therefore greatly increase the complexity and connectivity within legume agricultural landscapes required by many species of pollinators and natural enemies (Mkenda et al., 2019b).

Sufficient control of pests may not always be achievable by natural enemies alone in cases where pest populations are beyond the control of natural enemies. In such cases it is important to employ a measured approach to pesticides use by following guidelines and, most importantly, adopting Integrated Pest and Pollinator Management (IPPM) as part of an ecologically intensive strategy. This encompasses better training, use of the correct application equipment, utilizing less toxic alternatives, spraying outside blooming period and pollinator activity times. These approaches limit risks to pollinators, natural enemies and the environment while increasing the benefits of these pesticides to crops (Biddinger and Rajotte, $2015^{+}$).

\section{Regulations and policies to protect and promote pollination and natural pest regulation}

Protecting pollinators and natural pest enemies could be through the development of regulations and legislations using policy interventions that incentivize good practices (such as habitat protection and IPM) among farmers and citizens. Implementing policies that promote the utilization of pollinators and natural enemies of pests through a regulatory framework could be a 
1 viable tool for improving the sustainability of legume production. However, African countries

2 generally (apart from a few such as South Africa (Fabricius et al., 2003)), lack policies to formally guide the use of ecosystem driven natural resources, but regulations on how pollination and natural pest control services should be managed are urgently needed. Mirroring approaches taken by countries such as the Philippines, a comparatively low to middle-income country not unlike many in Africa, including institutionalization of farmer field schools and training on IPM (Furlong et al., 2019). However sufficient investment is needed from regional and national governments.

Many farmers in Africa already practice organic farming (Epule, 2019). Organic approaches could be further supported through incentives and policies that provide the necessary guidelines and framework within which organic farming can take place effectively to safeguard the environment and ecosystem services. This could be achieved through the provision of subsidies to farmers who practice environmentally-friendly farming or certification of products from such farms combined with facilitation to access suitable markets.

As identified in this review, multiple factors are acting together to impact the future of legume crop production in African agricultural landscapes. These impacts have knock-on effects on the well-being of pollinators and natural enemies of pests. This calls for adequate regulations and policies that will not only promote the production of legume crops but also safeguard pollinator and natural enemy species and guide the utilization of these ecosystem service providers.

In summary, six policy directions can benefit both pollinators and natural enemies of legume pests in Africa;

1. Development of beneficial insect friendly pesticide policies. This would result in the restriction of some of the most harmful pesticides affecting pollinators or natural enemies 
either directly or indirectly. This would be supported through better training for growers on using alternative pesticides and biological control approaches.

2. Extension of protected area policies to include key habitats that support pollinators and natural enemy communities essential to the production of legumes and other crops. These policies could provide information for the enhancement of beneficial insect habitats either through plantings or management in ways that ensure beneficial insects thrive. Extension services also need to include narratives of pollinator and natural enemy conservation practices in their encounters with farmers.

3. Development of a framework to incentivize farmers through programs such as payment for ecosystem services i.e. for farmers that grow pollinator-friendly crops to have a builtin incentive to manage their habitats for native pollinators (Rose et al., 2015 ${ }^{+}$. Governments could also consider tax benefits extended to farmers who practice pollinator-friendly farming.

4. Provision of a framework for ensuring representation in empowerment programs, certification of farmers who practice environmentally friendly farming (whether public or private-led) and market access for all stakeholders involved in legume crop production. This also includes indigenous farmers. Packages for protecting beneficial species need to be developed together with all stakeholders building on local knowledge gained from participatory encounters.

5. Recognition of the role of research in training experts and developing solutions to environmental problems especially those that threaten the existence of beneficial species. On this policy front, it is important to provide a framework for implementing research 
findings from pollination and natural pest regulation studies in advancing legume crop production.

6. Improved knowledge exchange between farmers, extension workers, researchers, NGOs and policymakers to highlight the multiple values of pollinators and natural enemies for improved nutritional, food and economic security. This could take the form of national training programmes, farmer field schools, participatory research, and evidence-based policy development.

\section{6) Conclusion}

Our review has demonstrated the important role played by pollinators and natural enemies in legume crop production in Africa and contributions of these organisms to food security. The review identifies agricultural intensification and population growth as the key drivers changing the landscapes used by beneficial organisms and threatening their future existence and the services they provide. Ecological intensification and organic farming offer novel solutions to safeguarding the ecosystem services provided by pollinators and natural enemies of pests. The application of ecological intensification through practices such as effective habitat management or establishment of boundary features, fallows, etc. in legume cropping systems can restore or maintain semi-natural and natural habitats suitable for beneficial insects. These habitats provide the much needed connectivity required by beneficial organisms within legume agricultural landscapes to sustain viable populations.

Finally, African countries need a holistic approach to raise awareness among farming communities and move towards the use of policies in the utilization of naturally occurring ecosystem services of pollination and natural pest regulation to formally protect these ecosystem services by reducing the environmental impacts of agriculture and its dependence on non- 
1 renewable resources to safeguard the legume crop base. This can be done through a more

2 promising avenue of ecological intensification using biodiversity-mediated ecosystem services to

3 support legume production.

\section{Declaration of conflict of interest}

5 None.

\section{Acknowledgments}

7 Funding: MO was supported by the Alexander von Humboldt Foundation through the Georg

8 Forster Fellowship for Experienced Researchers. 


\section{References}

Balzan, M. V., Bocci, G., Moonen, A.C., 2014. Augmenting flower trait diversity in wildflower strips to optimise the conservation of arthropod functional groups for multiple agroecosystem services. J. Insect Conserv. 18, 713-728. https://doi.org/10.1007/s10841-014-9680-2

Bartomeus, I., Potts, S.G., Steffan-Dewenter, I., Vaissière, B.E., Woyciechowski, M., Krewenka, K.M., Tscheulin, T., Roberts, S.P.M., Szentgyörgyi, H., Westphal, C., Bommarco, R., 2014. Contribution of insect pollinators to crop yield and quality varies with agricultural intensification. PeerJ 2, e328.

Belmain, S.R., Haggar, J., Holt, J. and Stevenson, P.C. (2013). Managing legume pests in subSaharan Africa: Challenges and prospects for improving food security and nutrition through agro-ecological intensification. Chatham Maritime (United Kingdom): Natural Resources Institute, University of Greenwich. 34p

Benachour, K., Louadi, K., Terzo, M., 2007. Role of wild and honey bees (Hymenoptera: Apoidea) in the pollination of Vicia faba L. var. major (Fabaceae) in Constantine area (Algeria). Ann. la Soc. Entomol. Fr. 43, 213-219.

Biddinger, D.J., Rajotte, E.G., 2015. Integrated pest and pollinator management - adding a new dimension to an accepted paradigm. Curr. Opin. Insect Sci. 10, 204-209. https://doi.org/10.1016/j.cois.2015.05.012

Bishop, J., Garratt, M. and Breeze, T. (2020) Yield benefits of additional pollination to faba bean vary with cultivar, scale, yield parameter and experimental method. Scientific Reports, 10. 2102. ISSN 2045-2322 doi: https://doi.org/10.1038/s41598-020-58518-1 
Blitzer, E.J., Dormann, C.F., Holzschuh, A., Klein, A.M., Rand, T.A., Tscharntke, T., 2012. Spillover of functionally important organisms between managed and natural habitats. Agric. Ecosyst. Environ. 146, 34-43. https://doi.org/10.1016/j.agee.2011.09.005

Bon, H., Huat, J., Parrot, L., Sinzogan, A., Martin, T., Malezieux, E., et al., 2014. Pesticides risks from fruits and vegetable pest management by small farmers in sub-saharan Africa. A review. Agronomy for Sustainable Development. 34(4):723-736

Bradbury, K.E., Tong, T.Y.N., Key, T.J., 2017. Dietary intake of high-protein foods and other major foods in meat-eaters, poultry-eaters, fish-eaters, vegetarians, and vegans in UK biobank. Nutrients 9. https://doi.org/10.3390/nu9121317

Brévault, T., Clouvel, P., 2019. Pest management: Reconciling farming practices and natural regulations. Crop Prot. 115, 1-6. https://doi.org/10.1016/j.cropro.2018.09.003

Cairns, C.E., Villanueva-gutiérrez, R., Koptur, S., David, B., Kluser, S., Peduzzi, P., Mayberry, R.J., Elle, E., 2017. Summary for policymakers of the assessment report of the intergovernmental science-policy platform on biodiversity and ecosystem services (IPBES) on pollinators, pollination and food. https://doi.org/10.1007/s00442-010-1809-8

Dainese, M. 2019. A global synthesis reveals biodiversity-mediated benefits for crop production. Science Advances 5, eaax0121

Deguines, N., Jono, C., Baude, M., Henry, M., Julliard, R., Fontaine, C., 2014. Large-scale tradeoff between agricultural intensification and crop pollination services. Front. Ecol. Environ. 12, 212-217. https://doi.org/10.1890/130054

Epule, T.E., 2019. Contribution of Organic Farming Towards Global Food Security, Organic Farming. Elsevier Inc. https://doi.org/10.1016/b978-0-12-813272-2.00001-X 
Erickson, E.H., Berger, G.A., Shannon, J.G., Robins, J.M., 1978. Honey Bee Pollination Increases Soybean Yields in the Mississippi Delta Region of Arkansas and Missouri 12. Journal of Economic Entomology 71, 601-603.

Eyhorn, F., Muller, A., Reganold, J.P. et al. Sustainability in global agriculture driven by organic farming. Nat Sustain 2, 253-255 (2019). https://doi.org/10.1038/s41893-019-0266-6

Fabricius, C., Matsiliza, B. and Sisitka, L. 2003. Laws, policies, international agreements and departmental guidelines that support community based natural resource management type programmes in South Africa. Pretoria, p29. (https://www.westerncape.gov.za/text/2004/5/updatestudy_cbnrm.pdf)

FAOSTAT, 2020. FAOSTAT: food and agriculture data. Available at: http://www.fao.org/ faostat/en/\#home, Accessed date: 20 March 2020.

Ferreira, P.A., Boscolo, D., Carvalheiro, L.G., Biesmeijer, J.C., Rocha, P.L.B., Viana, B.F., 2015. Responses of bees to habitat loss in fragmented landscapes of Brazilian Atlantic Rainforest. Landsc. Ecol. 30, 2067-2078. https://doi.org/10.1007/s10980-015-0231-3

Foyer, C.H., Lam, H-M., Nguyen, H.T., Siddique, K.H.M., Varshney, R.K., Colmer, T.D., et al., 2016 Neglecting legumes has compromised human health and sustainable food production. Nature Plants. 2:16112. DOI: 10.1038/nplants.2016.112

Franke, A.C., van den Brand, G.J., Vanlauwe, B., Giller, K.E., 2018. Sustainable intensification through rotations with grain legumes in Sub-Saharan Africa: A review. Agric. Ecosyst. Environ. 261, 172-185. https://doi.org/10.1016/j.agee.2017.09.029

Furlong, MJ; McDougall, SJ and Markham, RH. Enabling smallholders to tackle the challenges and opportunities offered by integrated crop management in contrasting cultural settings, in 
the Philippines and pacific islands [online]. Agricultural Science, Vol. 30/31, No. 2/1, 2019: $52-63$.

Garibaldi, L.A., Bartomeus, I., Bommarco, R., Klein, A.M., Cunningham, S.A., Aizen, M.A., Boreux, V., Garratt, M.P.D., Carvalheiro, L.G., Kremen, C., Morales, C.L., Schüepp, C., Chacoff, N.P., Freitas, B.M., Gagic, V., Holzschuh, A., Klatt, B.K., Krewenka, K.M., Krishnan, S., Mayfield, M.M., Motzke, I., Otieno, M., Petersen, J., Potts, S.G., Ricketts, T.H., Rundlöf, M., Sciligo, A., Sinu, P.A., Steffan-Dewenter, I., Taki, H., Tscharntke, T., Vergara, C.H., Viana, B.F., Woyciechowski, M., 2015. EDITOR'S CHOICE: REVIEW: Trait matching of flower visitors and crops predicts fruit set better than trait diversity. Journal of Applied Ecology 52, 1436-1444.

Garibaldi, L.A., Carvalheiro, L.G., Vaissière, B.E., Gemmill-Herren, B., Hipólito, J., Freitas, B.M., Ngo, H.T., Azzu, N., Sáez, A., Åström, J., An, J., Blochtein, B., Buchori, D., García, F.J.C., Oliveira da Silva, F., Devkota, K., Ribeiro, M.d.F., Freitas, L., Gaglianone, M.C., Goss, M., Irshad, M., Kasina, M., Filho, A.J.S.P., Kiill, L.H.P., Kwapong, P., Parra, G.N., Pires, C., Pires, V., Rawal, R.S., Rizali, A., Saraiva, A.M., Veldtman, R., Viana, B.F., Witter, S., Zhang, H., 2016. Mutually beneficial pollinator diversity and crop yield outcomes in small and large farms. Science 351, 388-391.

Garibaldi, L.A., Pérez-Méndez, N., Garratt, M.P.D., Gemmill-Herren, B., Miguez, F.E., Dicks, L. V., 2019. Policies for Ecological Intensification of Crop Production. Trends Ecol. Evol. 34, 282-286. https://doi.org/10.1016/j.tree.2019.01.003

Garibaldi, L.A., Steffan-Dewenter, I., Winfree, R., Aizen, M.A., Bommarco, R., Cunningham, S.A., Kremen, C., Carvalheiro, L.G., Harder, L.D., Afik, O. and 40 others. 2013. Wild 
pollinators enhance fruit set of crops regardless of honey bee abundance. Science 339(6127):1608-1611.

Garratt, M. P. D., Coston, D. J., Truslove, C.L., Lappage, M.G., Polce, C., Dean, R., Biesmeijer, J.C. and Potts, S. G. (2014) The identity of crop pollinators helps target conservation for improved ecosystem services. Biological Conservation, 169. pp. 128-135. ISSN 0006-3207 doi: https://doi.org/10.1016/j.biocon.2013.11.001

Garratt, M.P.D., Potts, S.G., Banks, G., Hawes, C., Breeze, T.D., O’Connor, R.S., Carvell, C., 2019. Capacity and willingness of farmers and citizen scientists to monitor crop pollinators and pollination services. Global Ecology and Conservation. Vol. 20: e00781 doi.org/10.1016/j.gecco.2019.e00781

Gemmill-Herren, B., Kawapong Kawapong, P., Aidoo, K., Martins, D., Kinuthia, W., Gikungu, M., Desmond Eardley, C., 2014. Priorities for research and development in the management of pollination services for agricultural development in Africa. J. Pollinat. Ecol. 12. https://doi.org/10.26786/1920-7603(2014)1

Gentz, M.C., Murdoch, G., King, G.F., 2010. Tandem use of selective insecticides and natural enemies for effective, reduced-risk pest management. Biol. Control 52, 208-215. $\underline{\text { https://doi.org/10.1016/j.biocontrol.2009.07.012 }}$

Greenop, A., Woodcock, B.A., Wilby, A., Cook, S.M., Pywell, R.F., 2018. Functional diversity positively affects prey suppression by invertebrate predators: a meta-analysis. Ecology 99, 1771-1782.

Grzywacz, D., Stevenson, P.C., Mushobozi, W.L., Belmain, S., Wilson, K., 2014. The use of indigenous ecological resources for pest control in Africa. Food Secur. 6, 71-86. https://doi.org/10.1007/s12571-013-0313-5 
Guenat, S., Kunin, W.E., Dougill, A.J., Dallimer, M., 2019. Effects of urbanisation and management practices on pollinators in tropical Africa. J. Appl. Ecol. 56, 214-224. https://doi.org/10.1111/1365-2664.13270

Gulzar, M., Minnaar, A., 2016. Underutilized Protein Resources From African Legumes, Sustainable Protein Sources. Elsevier Inc. https://doi.org/10.1016/B978-0-12-802778-

$$
\underline{3.00012-3}
$$

Hassanali, A., Herren, H., Khan, Z. R., Pickett, J. A., \& Woodcock, C. M. (2008). Integrated pest management: The push-pull approach for controlling insect pests and weeds of cereals, and its potential for other agricultural systems including animal husbandry. Philosophical Transactions of the Royal Society B, 363, 611-621.

Islam, I., Adam, Z., Islam, S., 2019. Soybean (Glycine Max): Alternative Sources of Human Nutrition and Bioenergy for the 21st Century. Am. J. Food Sci. Technol. 7, 1-6. $\underline{\text { https://doi.org/10.12691/ajfst-7-1-1 }}$

Jacquemin, F., Violle, C., Rasmont, P., and Dufrêne, M. 2017 Mapping the dependency of crops on pollinatorsin Belgium. One Ecosystem 2: e13738. https://doi.org/10.3897/oneeco.2.e13738

Karp et al., 2018. Crop pests and predators exhibit inconsistent responses to surrounding landscape composition. Proceedings of the National Academy of Sciences.

Keating, B.A., Carberry, P.S., Dixon, J. 2013 Agriculturalintensificationandthefoodsecurity challenge in sub-Saharan Africa. In Agroecological Intensification of Agricultural Systems in the African Highlands. Edited by Vanlauwe B, Van Asten P, Blomme G. UK: Earth scan. 
1 Kebede, Y., Bianchi, F.J.J.A., Baudron, F., Abraham, K., de Valença, A., Tittonell, P. 2018. Implications of changes in land cover and landscape structure for the biocontrol potential of stemborers in Ethiopia Biol. Control., 122, pp. 1-10

Kerr, J.T., Pindar, A., Galpern, P., Packer, L., Potts, S.G., Roberts, S.M., Rasmont, P., Schweiger, O., Colla, S.R., Richardson, L.L., Wagner, D.L., Gall, L.F., Sikes, D.S., Pantoja, A., 2015. Climate change impacts on bumblebees converge across continents. Science 349, $177-180$.

Klein, A., Vaissière, B.E., Cane, J.H., Steffan-Dewenter, I., Cunningham, S.A., Kremen, C.,Tscharntke, T. 2007 Importance of pollinators in changing landscapes for world crops. Proc. Royal Soc. B. Biol., 274 (1608): 303-313. https://doi.org/10.1098/rspb.2006.3721

Kovács-Hostyánszki, A., Espíndola, A., Vanbergen, A.J., Settele, J., Kremen, C., Dicks, L. V., 2017. Ecological intensification to mitigate impacts of conventional intensive land use on pollinators and pollination. Ecol. Lett. 20, 673-689. https://doi.org/10.1111/ele.12762

Krauss J, Gallenberger I, Steffan-Dewenter I (2011) Decreased Functional Diversity and Biological Pest Control in Conventional Compared to Organic Crop Fields. PLoS ONE 6: e19502.

Lamarque, P., Quétier, F., Lavorel, S., 2011. The diversity of the ecosystem services concept and its implications for their assessment and management. Comptes Rendus - Biol. 334, 441-449. https://doi.org/10.1016/j.crvi.2010.11.007

Martin, E.A. et al 2019. The interplay of landscape composition and configuration: new pathways to manage functional biodiversity and agroecosystem services across Europe. Ecology Letters 22, 1083-1094. 
Martins, D.J., 2013. People, Plants and Pollinators: Uniting Conservation, Food Security, and Sustainable Agriculture in East Africa.

Merga B. and \& Haji J., 2019. Economic importance of chickpea: Production, value, and world trade, Cogent Food \& Agriculture, 5:1, DOI: 10.1080/23311932.2019.1615718

Mkenda, Ndakidemi, Stevenson, Arnold, Belmain, Chidege, Gurr, Woolley, 2019. Characterization of Hymenopteran Parasitoids of Aphis fabae in an African Smallholder Bean Farming System through Sequencing of COI 'Mini-Barcodes.' Insects 10, 331. https://doi.org/10.3390/insects 10100331

Mkenda, Prisila A., Ndakidemi, Patrick A., Mbega, Ernest, Stevenson, Philip C., Arnold, Sarah E.J. , Gurr, Geoff M. and Belmain, Steven R. (2019) Multiple ecosystem services from field margin vegetation for ecological sustainability in agriculture: scientific evidence and knowledge gaps. PeerJ, 7:e8091. ISSN 2376-5992 (Online) (doi:https://doi.org/10.7717/peerj.8091).

Mkenda, Prisila, Ndakidemi, Patrick A, Stevenson, Philip , Arnold, Sarah, Belmain, Steven R. , Chidege, M and Gurr, Geoff M (2019) Field margin vegetation in tropical African bean systems harbours diverse natural enemies for biological pest control in adjacent crops. Sustainability, 11 (22):6399. ISSN 2071-1050 (Online) (doi:https://doi.org/10.3390/su11226399)

Muli, E., Patch, H., Frazier, M., Frazier, J., Torto, B., et al., 2014. Evaluation of the distribution and impacts of parasites, pathogens, and pesticides on honey bee (Apis mellifera) populations in East Africa. PLoS One, 9(4), e94459. https://doi.org/10.1371/journal.pone.0094459

Muoni, T., Barnes, A.P., Öborn, I., Watson, C.A., Bergkvist, G., Shiluli, M. and Duncan, A.J. (2019) Farmer perceptions of legumes and their functions in smallholder farming systems in 
east Africa, International Journal of Agricultural Sustainability, 17:3, 205-218, DOI: $10.1080 / 14735903.2019 .1609166$

Mwangi, D., Kasina, M., Nderitu, J., Hagen, M., Gikungu, M., Kraemer, M., 2012. Diversity and abundance of native bees foraging on hedgerow plants in the Kakamega farmlands, western Kenya. J. Apic. Res. 51, 298-305. https://doi.org/10.3896/IBRA.1.51.4.02

Nayak, G. K., Roberts, S. P. M., Garratt, M., Breeze, T. D., Tscheulin, T., Harrison-Cripps, J., Vogiatzakis, I. N., Stirpe, M. T. and Potts, S. G. (2015) Interactive effect of floral abundance and semi-natural habitats on pollinators in field beans (Vicia faba). Agriculture Ecosystems \& Environment, 199. pp. 58-66. ISSN 0167-8809 doi: https://doi.org/10.1016/j.agee.2014.08.016

Ndakidemi, B., Mtei, K. and Ndakidemi, P.A., 2016. The Potential of Common Beneficial Insects and Strategies for Maintaining Them in Bean Fields of Sub Saharan Africa. American Journal of Plant Sciences, 7, 425-436. http://dx.doi.org/10.4236/ajps.2016.73036.

Nedumaran S, Abinaya P, Jyosthnaa P, Shraavya B, P.R. and C.B., 2015. Grain Legumes Production, Consumption and Trade Trends in Developing Countries. Working Paper Series No 60. ICRISAT Research Program, Markets, Institutions and Policies 64 pp.

Nemésio, A., Silva, D.P., Nabout, J.C., Varela, S., 2016. Effects of climate change and habitat loss on a forest-dependent bee species in a tropical fragmented landscape. Insect Conserv. Divers. 9, 149-160. https://doi.org/10.1111/icad.12154

Ojiewo, C., Keatinge, D.J.D.H., Hughes, J., Tenkouano, A., Nair, R., Varshney, R., Siambi, M., Monyo, E., Ganga-Rao, N., Silim, S., 2015. The Role of Vegetables and Legumes in 
Assuring Food, Nutrition, and Income Security for Vulnerable Groups in Sub-Saharan Africa. World Med. Heal. Policy 7, 187-210. https://doi.org/10.1002/wmh3.148

Pasquet, R.S., Peltier, A., Hufford, M.B., Oudin, E., Saulnier, J., Paul, L., Knudsen, J.T., Herren, H.R., Gepts, P. (2008) Proceedings of the National Academy of Sciences. 105 (36) 13456-13461; DOI: 10.1073/pnas.0806040105

Peh et al., (2013) TESSA: A toolkit for rapid assessment of ecosystem services at sites of biodiversity conservation importance. Ecosystem Services5, 51-55 http://tessa.tools/.

Peters MK, Hemp A, Appelhans T, Becker JN, Behler C, Classen A, Detsch F, Ensslin A, Ferger SW, Frederiksen SB, Gebert FD, Gerschlauer F, Gütlein A, Helbig-Bonitz M, Hemp C, Kindeketa WJ, Kühnel A, Mayr AV, Mwangomo E, Ngereza C, Njovu HK, Otte I, Pabst H, Renner M, Röder J, Rutten G, Schellenberger Costa D, Sierra-Cornejo N, Vollstädt MGR, Dulle HI, Eardley CD, Howell KM, Keller A, Peters RS, Ssymank A, Kakengi V, Zhang J, Bogner C, Bohning-Gaese K, Brandl R, Hertel D, Huwe B, Kiese R, Kleyer M, Kuzyakov Y, Nauss T, Schleuning M, Tschapka M, Fischer M, Steffan-Dewenter I (2019) Climate-landuse interactions shape tropical mountain biodiversity and ecosystem functions. Nature 568: $88-92$.

Pleasant, J. 2016. Food Yields and Nutrient Analyses of the Three Sisters: A Haudenosaunee Cropping System. Ethnobiology Letters 7(1):87-98. DOI 10.14237/ebl.7.1.2016.721

Potts, S.G., Imperatriz-Fonseca, V., Ngo, H.T., Aizen, M.A., Biesmeijer, J.C., Breeze, T.D., Dicks, L.V., Garibaldi, L.A., Hill, R., Settele, J., Vanbergen, A.J., 2016. Safeguarding pollinators and their values to human well-being. Nature 540, 220-229 
1 Pretty, J., Bharucha, Z.P., 2015. Integrated pest management for sustainable intensification of agriculture in Asia and Africa. Insects 6, 152-182. https://doi.org/10.3390/insects6010152

Ramsden, M.W., Menéndez, R., Leather, S.R., Wäckers, F., 2014. Optimizing field margins for

4 biocontrol services: The relative role of aphid abundance, annual floral resources, and

Redlich S, Martin EA, Steffan-Dewenter I (2018) Landscape-level crop diversity benefits biological pest control. Journal of Applied Ecology 55: 2419-2428.

Rose, T., Kremen, C., Thrupp, L.A., 2015. Policies to Protect Pollinators: Actions Needed to Avert a Global Crisis in Agriculture. Berkeley Food Inst. 1-6. https://doi.org/10.1016/j.bios.2017.11.044

Schneider G, Krauss J, Riedinger V, Holzschuh A, Steffan-Dewenter I (2015) Biological pest control and yields depend on spatial and temporal crop cover dynamics. Journal of Applied Ecology 52: 1283-1292

Siviter, H., Koricheva, J., Brown, M.J.F., Leadbeater, E. 2018 Quantifying the impact of pesticides on learning and memory in bees (ed M Pocock) J Appl Ecol. 2018b;55:28122821. doi: $10.1111 / 1365-2664.13193$

Snapp, S.S., Cox, C.M., Peter, B.G., 2019. Multipurpose legumes for smallholders in subSaharan Africa: Identification of promising 'scale out' options. Glob. Food Sec. 23, 22-32. https://doi.org/10.1016/j.gfs.2019.03.002

Snyder, W.E., 2019. Give predators a complement: Conserving natural enemy biodiversity to improve biocontrol. Biol. Control 135, 73-82. https://doi.org/10.1016/j.biocontrol.2019.04.017 
1 Stagnari, F., Maggio, A., Galieni, A., Pisante, M., 2017. Multiple benefits of legumes for

agriculture sustainability: an overview. Chem. Biol. Technol. Agric. 4, 1-13. https://doi.org/10.1186/s40538-016-0085-1

Suso, M.J., Bebeli, P.J., Christmann, S., Mateus, C., Negri, V., Pinheiro de Carvalho, M.A.A., Torricelli, R., Veloso, M.M., 2016. Enhancing legume ecosystem services through an understanding of plant-pollinator interplay. Front. Plant Sci. 7, 1-18. https://doi.org/10.3389/fpls.2016.00333

Tscharntke, T., Klein, A.M., Kruess, A., Steffan-Dewenter, I., Thies, C., 2005. Landscape perspectives on agricultural intensification and biodiversity - Ecosystem service management. Ecol. Lett. 8, 857-874. https://doi.org/10.1111/j.1461-0248.2005.00782.x

United Nations, Department of Economic and Social Affairs, Population Division (2019). World Population Prospects 2019: Highlights (ST/ESA/SER.A/423).

Vaissière, B.E., Magalhães Freitas, B.M. and Gemmill-Herren, B. 2011. Protocol to Detect and Assess Pollination Deficits in Crops: A Handbook for its Use. FAO. Rome: FAO, 83 p.

Valk, H. Van Der, Koomen, I., Nocelli, R.C.F., Ribeiro, M.D.F., Freitas, B.M., Carvalho, S., Kasina, J.M., Martins, D., Mutiso, M., Odhiambo, C., Gikungu, M., Ngaruiya, P., Maina, G., Kipyab, P., Blacquière, T., 2012. Aspects determining the risk of pesticides to wild bees: risk profiles for focal crops on three continents. Julius-Kühn-Archiv 142-158. https://doi.org/10.5073/jka.2012.437.042

Vanlauwe, B. Hungria, M. Kanampiu, F. Giller, K.E. (2019) The role of legumes in the sustainable intensification of African smallholder agriculture: Lessons learnt and challenges for the future. Agriculture, Ecosystems \& Environment. 284; 106583 
1 Woodcock, B.A., Isaac, N.J.B., Bullock, J.M., Roy, D.B., Garthwaite, D.G., Crowe, A., Pywell, R.F., 2016. Impacts of neonicotinoid use on long-term population changes in wild bees in England. Nature Communications 7, 12459.

4 Woodcock, B.A., Garratt, M.P.D., Powney, G.D., Shaw, R.F., Osborne, J.L., Soroka, J., 5 Lindström, S.A.M., Stanley, D., Ouvrard, P., Edwards, M.E., Jauker, F., McCracken, M.E., 6 Zou, Y., Potts, S.G., Rundlöf, M., Noriega, J.A., Greenop, A., Smith, H.G., Bommarco, R., 7 van der Werf, W., Stout, J.C., Steffan-Dewenter, I., Morandin, L., Bullock, J.M., Pywell, 8 R.F., 2019. Meta-analysis reveals that pollinator functional diversity and abundance enhance $9 \quad$ crop pollination and yield. Nature Communications 10, 1481. natural enemies to control aphids. Sci. Rep. 5, 8024. https://doi.org/10.1038/srep08024 


\section{Appendix 1: Table showing harvested area, production and yield of major legume food crops in Africa from \\ 22000 to 2018 (Source: FAOSTAT 2020)}

\begin{tabular}{|c|c|c|c|c|c|c|c|c|c|}
\hline Changes & Dry beans & Broad & Chick peas & Cow peas & Lentils & Lupins & Dry peas & Pigeon & Soybeans \\
\hline \multicolumn{10}{|c|}{ Mean area harvested (ha) } \\
\hline $2000-2002$ & 4868615.33 & 803568.33 & 503042.67 & 9125406.67 & 133829.33 & 46909.33 & 485898.00 & 530418.67 & 947208.33 \\
\hline $2003-2005$ & 5565534.67 & 851428.67 & 477593.00 & 9744456.00 & 122533.00 & 56411.33 & 554096.67 & 580059.67 & 1127680.00 \\
\hline $2006-2008$ & 5771109.67 & 882322.00 & 498695.33 & 11604309.00 & 146890.33 & 71807.33 & 554279.67 & 567059.67 & 1293698.00 \\
\hline $2009-2011$ & 6556346.00 & 905644.67 & 529249.00 & 10265708.67 & 158816.67 & 81605.33 & 661859.00 & 568933.00 & 1317029.67 \\
\hline $2012-2014$ & 7602270.67 & 920938.67 & 624007.67 & 11821643.00 & 183476.33 & 92688.00 & 733444.33 & 798486.33 & 1771850.00 \\
\hline $2015-2018$ & 7397390.00 & 779496.50 & 516803.75 & 12079017.50 & 172193.75 & 102512.75 & 657090.50 & 720141.5 & 2214297.00 \\
\hline $\begin{array}{l}\text { Change in area } \\
\text { (2000 to 2018) }\end{array}$ & -204880.67 & -141442.17 & -107203.92 & 257374.50 & -11282.58 & 9824.75 & -76353.83 & -78344.83 & 442447.00 \\
\hline \% Change & -2.69 & -15.36 & -17.18 & 2.18 & -6.15 & 10.60 & -10.41 & -9.81 & 24.97 \\
\hline Growth rate per & -0.01 & -0.03 & -0.06 & 0.02 & 0.01 & 0.03 & -0.01 & 0.01 & 0.05 \\
\hline \%Growth & -0.77 & -3.30 & -6.21 & 1.80 & 0.87 & 3.29 & -1.03 & 0.69 & 5.06 \\
\hline \multicolumn{10}{|c|}{ Mean production (tons) } \\
\hline $2000-2002$ & 3325776.67 & 1069773.33 & 346952.33 & 3540293.67 & 80572.33 & 39562.00 & 313561.67 & 357054.00 & 1000311.67 \\
\hline $2003-2005$ & 3407923.33 & 1145608.00 & 334639.00 & 4180280.00 & 76424.33 & 39406.67 & 382376.67 & 387926.67 & 1166677.67 \\
\hline $2006-2008$ & 4082267.33 & 1246123.67 & 419926.33 & 5253550.67 & 102486.33 & 52863.67 & 411754.67 & 430515.33 & 1412246.00 \\
\hline $2009-2011$ & 5267471.00 & 1311391.67 & 552424.33 & 5145383.67 & 155586.33 & 59056.00 & 533382.00 & 487499.67 & 1555899.67 \\
\hline $2012-2014$ & 6207657.00 & 1477546.67 & 704242.67 & 7148536.33 & 194956.67 & 65739.33 & 673256.00 & 745091.67 & 2120059.00 \\
\hline $2015-2018$ & 6756959.5 & 1363019.5 & 717333 & 6588501.25 & 213987.75 & 72143.5 & 632927.75 & 878497.25 & 2861969.75 \\
\hline $\begin{array}{l}\text { Change in } \\
\text { production (2000- } \\
\text { 2018) }\end{array}$ & 549302.50 & -114527.17 & 13090.33 & -560035.08 & 19031.08 & 6404.17 & -40328.25 & 133405.58 & 741910.75 \\
\hline$\%$ Change & 8.85 & -7.75 & 1.86 & -7.83 & 9.76 & 9.74 & -5.99 & 17.90 & 34.99 \\
\hline Growth rate per & 0.02 & -0.01 & -0.00 & -0.01 & 0.04 & 0.03 & 0.01 & 0.08 & 0.09 \\
\hline \%Growth & 2.32 & -1.36 & -0.23 & -0.53 & 3.77 & 3.17 & 0.51 & 7.55 & 8.81 \\
\hline \multicolumn{10}{|c|}{ Mean yield (ton/ha) } \\
\hline $2000-2002$ & 0.68 & 1.33 & 0.69 & 0.39 & 0.60 & 0.85 & 0.64 & 0.67 & 1.06 \\
\hline $2003-2005$ & 0.61 & 1.34 & 0.70 & 0.43 & 0.63 & 0.69 & 0.69 & 0.67 & 1.03 \\
\hline $2006-2008$ & 0.71 & 1.42 & 0.84 & 0.45 & 0.70 & 0.74 & 0.74 & 0.76 & 1.09 \\
\hline $2009-2011$ & 0.80 & 1.45 & 1.04 & 0.50 & 0.98 & 0.72 & 0.81 & 0.85 & 1.19 \\
\hline $2012-2014$ & 0.82 & 1.61 & 1.13 & 0.61 & 1.07 & 0.71 & 0.92 & 0.93 & 1.20 \\
\hline $2015-2018$ & 0.90 & 1.86 & 1.43 & 0.57 & 1.22 & 0.70 & 1.02 & 1.16 & 1.36 \\
\hline & & & & & & & & & \\
\hline $\begin{array}{l}\text { Change in yield } \\
(2000 \text { to 2018) }\end{array}$ & 0.10 & 0.14 & 0.26 & -0.06 & 0.18 & -0.01 & 0.05 & 0.29 & 0.09 \\
\hline Growth rate/year & 11.73 & 9.01 & 22.87 & -10.57 & 17.24 & -0.79 & 5.16 & 30.98 & 7.32 \\
\hline \%Growth & 0.03 & 0.02 & 0.07 & -0.02 & 0.03 & -0.00 & 0.01 & 0.07 & 0.03 \\
\hline
\end{tabular}


1 Appendix 2a: Table of search criteria for legume pollination related studies done in Africa

\begin{tabular}{|c|c|c|c|c|}
\hline $\mathbf{S} / \mathbf{N}$ & Region & Search terms & $\begin{array}{l}\text { Number } \\
\text { of } \\
\text { papers }\end{array}$ & Criteria \\
\hline 1 & $\begin{array}{l}\text { Eastern } \\
\text { Africa }\end{array}$ & $\begin{array}{l}\text { legume Pollinat* AND “Eastern } \\
\text { Africa” OR "Burundi" OR } \\
\text { "Comoros" OR "Djibouti" OR "Ethiopia" } \\
\text { OR "Eritrea" OR "Kenya" OR } \\
\text { "Madagascar" OR "Malawi" OR } \\
\text { "Mauritius" OR "Mozambique" OR } \\
\text { "Réunion" OR "Rwanda" OR } \\
\text { "Seychelles" OR "Somalia" OR } \\
\text { "Somaliland" OR "Tanzania" OR } \\
\text { "Uganda" OR "Zambia" OR "Zimbabwe" }\end{array}$ & 23,633 & \multirow{5}{*}{$\begin{array}{l}\text { Refined search by research } \\
\text { articles or review papers in } \\
\text { ecology or environmental } \\
\text { science/studies or entomology }\end{array}$} \\
\hline 2 & $\begin{array}{l}\text { Western } \\
\text { Africa }\end{array}$ & $\begin{array}{l}\text { legume Pollinat* AND "Western } \\
\text { Africa" OR "Benin" OR "Burkina Faso" } \\
\text { OR } \\
\text { "Cape Verde" OR "Côte d'Ivoire" OR } \\
\text { "Ivory Coast" OR "Gambia" OR } \\
\text { "Ghana" OR } \\
\text { "Guinea-Bissau" OR "Liberia" OR } \\
\text { "Mali" OR "Mauritania" OR "Niger" } \\
\text { OR "Nigeria" OR "Saint Helena" OR } \\
\text { "Ascension" OR "Tristan da Cunha" } \\
\text { "Senegal" OR "Sierra Leone" OR } \\
\text { "Togo" }\end{array}$ & 18,687 & \\
\hline 3 & $\begin{array}{l}\text { Northern } \\
\text { Africa }\end{array}$ & $\begin{array}{l}\text { legume Pollinat* AND "Northern } \\
\text { Africa” OR "Algeria" OR "Egypt" OR } \\
\text { "Libya" OR "Morocco" OR } \\
\text { "Sudan" OR "Tunisia" } \\
\text { OR "Western Sahara" }\end{array}$ & 17,561 & \\
\hline 4 & $\begin{array}{l}\text { Southern } \\
\text { Africa }\end{array}$ & $\begin{array}{l}\text { legume Pollinat* AND "Southern } \\
\text { Africa” OR "Botswana" OR } \\
\text { "Lesotho" OR "Namibia" OR "South } \\
\text { Africa" OR "Swaziland" OR "Eswatini" }\end{array}$ & 25,993 & \\
\hline 5 & $\begin{array}{l}\text { Central } \\
\text { Africa }\end{array}$ & $\begin{array}{l}\text { legume Pollinat* AND “Central } \\
\text { Africa” OR "Angola" OR "Cameroon" } \\
\text { OR "Central African Republic" OR } \\
\text { "Chad" OR "Congo Republic" OR } \\
\text { "Democratic Republic of Congo" OR } \\
\text { "Equatorial Guinea" OR "Gabon" OR } \\
\text { "São Tomé ? Principe" }\end{array}$ & 2,647 & \\
\hline
\end{tabular}




\section{Appendix 2b: Table of search criteria for legume natural pest control related studies done}

\section{2 in Africa}

\begin{tabular}{|c|c|c|c|c|}
\hline $\mathrm{S} / \mathrm{N}$ & Region & Search terms & $\begin{array}{l}\text { Number } \\
\text { of } \\
\text { papers }\end{array}$ & Criteria \\
\hline 1 & $\begin{array}{l}\text { Eastern } \\
\text { Africa }\end{array}$ & $\begin{array}{l}\text { legume "natural enemies" OR “natural } \\
\text { pest enemies” OR "biocontrol” OR } \\
\text { "biological control" AND "Eastern } \\
\text { Africa" OR "Burundi" OR "Comoros" } \\
\text { OR "Djibouti" OR "Ethiopia" OR } \\
\text { "Eritrea" OR "Kenya" OR "Madagascar" } \\
\text { OR "Malawi" OR "Mauritius" OR } \\
\text { "Mozambique" OR "Réunion" OR } \\
\text { "Rwanda" OR "Seychelles" OR } \\
\text { "Somalia" OR "Somaliland" OR } \\
\text { "Tanzania" OR "Uganda" OR "Zambia" } \\
\text { OR "Zimbabwe" }\end{array}$ & 26,459 & \multirow{5}{*}{$\begin{array}{l}\text { Refined search by research } \\
\text { articles or review papers in } \\
\text { ecology or environmental } \\
\text { science/studies or entomology }\end{array}$} \\
\hline 2 & $\begin{array}{l}\text { Western } \\
\text { Africa }\end{array}$ & $\begin{array}{l}\text { legume "natural enemies" OR "natural } \\
\text { pest enemies" OR "biocontrol" OR } \\
\text { "biological control" AND "Western } \\
\text { Africa" OR "Benin" OR "Burkina Faso" } \\
\text { OR "Cape Verde" OR "Côte d'Ivoire" } \\
\text { OR "Ivory Coast" OR "Gambia" OR } \\
\text { "Ghana" OR "Guinea-Bissau" OR } \\
\text { "Liberia" OR "Mali" OR "Mauritania" } \\
\text { OR "Niger" OR "Nigeria" OR "Saint } \\
\text { Helena" OR "Ascension" OR "Tristan da } \\
\text { Cunha" } \\
\text { "Senegal" OR "Sierra Leone" OR } \\
\text { "Togo" }\end{array}$ & 24,635 & \\
\hline 3 & $\begin{array}{l}\text { Northern } \\
\text { Africa }\end{array}$ & $\begin{array}{l}\text { legume "natural enemies" OR "natural } \\
\text { pest enemies" OR "biocontrol" OR } \\
\text { "biological control” AND "Northern } \\
\text { Africa" OR "Algeria" OR "Egypt" OR } \\
\text { "Libya" OR "Morocco" OR "Sudan" OR } \\
\text { "Tunisia" } \\
\text { OR "Western Sahara" }\end{array}$ & 26,721 & \\
\hline 4 & $\begin{array}{l}\text { Southern } \\
\text { Africa }\end{array}$ & $\begin{array}{l}\text { legume "natural enemies" OR "natural } \\
\text { pest enemies" OR "biocontrol" OR } \\
\text { "biological control" AND "Southern } \\
\text { Africa" OR "Botswana" OR "Lesotho" } \\
\text { OR "Namibia" OR "South Africa" OR } \\
\text { "Swaziland" OR "Eswatini" }\end{array}$ & 35,026 & \\
\hline 5 & $\begin{array}{l}\text { Central } \\
\text { Africa }\end{array}$ & $\begin{array}{l}\text { legume "natural enemies" OR "natural } \\
\text { pest enemies" OR "biocontrol" OR } \\
\text { "biological control" AND "Central } \\
\text { Africa" OR "Angola" OR "Cameroon" } \\
\text { OR "Central African Republic" OR } \\
\text { "Chad" OR "Congo Republic" OR } \\
\text { "Democratic Republic of Congo" OR } \\
\text { "Equatorial Guinea" OR "Gabon" OR } \\
\text { "São Tomé ? Principe" }\end{array}$ & 13,939 & \\
\hline
\end{tabular}




\section{Appendix 3a: References to pollination studies on legume crops in Africa}

Aouar-Sadli, M., Louadi, K. and Doumandji, S.E. (2008) Pollination of the broad bean (Vicia faba L. var. major) (Fabaceae) by wild bees and honey bees (Hymenoptera: Apoidea) and its impact on the seed production in the Tizi-Ouzou area (Algeria) African Journal of Agricultural Research, 3, pp. 266-272.

Asiwe, J.(2009) Insect mediated outcrossing and geneflow in cowpea (Vigna unguiculata (L.) Walp): Implication for seed production and provision of containment structures for genetically transformed cowpea. African Journal of Biotechnology. 8(2): 226-230.

Benachour, K., Louadi, K., Terzo, M., 2007. Role of wild and honey bees (Hymenoptera : Apoidea) in the pollination of Vicia faba L. var. major (Fabaceae) in Constantine area (Algeria). Ann. la Soc. Entomol. Fr. 43, 213-219.

Blettler, D.C., FAGÚNDEZ, G.A. \& CAVIGLIA, O.P. Contribution of honeybees to soybean yield. Apidologie 49, 101-111 (2018) doi:10.1007/s13592-017-0532-4

de Milfont, M., Rocha, E. Emanuela M, Lima, A. Odério N, \& Freitas, B. M. (2013). Higher soybean production using honeybee and wild pollinators, a sustainable alternative to pesticides and autopollination. Environmental chemistry letters, 11, 335-341. doi: 10.1007/s10311-013-0412-8

Douka C, Tamesse JL, Tchuenguem FF. (2017) Impact of single visit of Lipotriches collaris Vachal 1903 (Hymenoptera: Halictidae) on Phaseolus vulgaris (Fabaceae) flowers at Maroua (Cameroon). J App Biol Biotech. 5 (02): 072-076. DOI: 10.7324/JABB.2017.50211

Douka C, Tchuenguem FFN. (2013) Foraging and pollination behavior of Apis mellifera adansonii L. (Hymenoptera, Apidae) on Phaseolus vulgaris (Fabaceae) flowers at Maroua (Cameroon). International Journal of Plant Sciences. 4(2): 45 - 54.

Fatokun, C. (2007) Outcrossing in cowpea. Journal of Food Agriculture and Environment 5(3): 334-338.

Fohouo, F.N.T., Ngakou, A., Kengni, B.S., 2009. Pollination and yield responses of cowpea (Vigna unguiculata L. Walp.) to the foraging activity of Apis mellifera adansonii (Hymenoptera: Apidae) at Ngaoundéré (Cameroon). African J. Biotechnol. 8, 1988-1996.

Fohouo, F.T., 2014. Pollination efficiency of Xylocopa olivacea ( Hymenoptera : Apidae ) on Pollination efficiency of Xylocopa olivacea ( Hymenoptera : Apidae ) on Cajanus cajan ( Fabaceae ) flowers at Yaounde. https://doi.org/10.1017/S1742758414000307

Gasim, S.M. and Abdelmula, A.A. (2018) Impact of Bee Pollination on Yield of Faba Bean (Vicia faba L.) Grown under Semi-Arid Conditions. Agricultural Sciences, 9, 729-740. https://doi.org/10.4236/as.2018.96051 
Horneburg B (2006) Short communication: outcrossing in lentil (Lens culinaris) depends on cultivar, location and year, and varies within cultivars. Plant Breeding 125, 638-640.

Ige, O.E., Olotuah, O.F., Akerele, V., 2011. Floral biology and pollination ecology of cowpea (Vigna Unguiculata L. Walp). Mod. Appl. Sci. 5, 74-82. https://doi.org/10.5539/mas.v5n4p74

Kasina J. M., Hagen M. L., Kraemer M., Nderitu J., Martius C., Wittmann D. (2009a). Bee pollination enhances crop yield and fruit quality in Kakamega, western Kenya. E. Afr. Agric. For. J. 75 1-11.

Kasina, J.M., Mburu, J., Kraemer, M., Holm-Mueller, A.K., 2009b. Economic Benefit of Crop Pollination by Bees: A Case of Kakamega Small-Holder Farming in Western Kenya, J. Econ. Entomol.

Kennedy, C.M., Lonsdorf, E., Neel, M.C., Williams, N.M., Taylor, H., Winfree, R., Brittain, C., Alana, L., Cariveau, D., 2013. A global quantitative synthesis of local and landscape effects on wild bee pollinators in agroecosystems. https://doi.org/10.1111/ele.12082

Latif, A., Malik, S.A., Saeed, S., Iqbal, N., Saeed, Q., Khan, K.A., Ting, C., Ghramh, H.A., 2019. Diversity of pollinators and their role in the pollination biology of chickpea, Cicer arietinum L. (Fabaceae). J. Asia-Pac. Entomol. 22, 597-601.

Masiga, R., Kasina, M., Mbugi, J., Odhiambo, C., Kinuthia, W., Gemmill-Herren, B., Vaissiere, B., 2014. Do french beans (Phaseolus vulgaris L.) grown in proximity to Mt Kenya forestKenya-experience pollination deficit? J. Pollinat. Ecol. 14, 255-260. https://doi.org/10.26786/1920-7603(2013)25

Mazi S., Fohouo F.N. and Bruckner D. 2014 Foraging and pollination behaviour of Chalicodoma rufipes (Hymenopters: Megachilida) on Cajanus cajan (L.) Millsp. (Fabaceae) flowers at Dang (Cameroon). Intl. J. Agro. Agril. Res. 4, 77-88.

Musa, A.K., Liadi, M. T., and Adegbite, O. R. (2013) Impact of honeybees (Apis mellifera adansonii) (Hymenoptera: Apidae) pollination on pod and seed set of cowpea (Vigna unguiculata L. Walp) in Ilorin, Southern Guinea Savanna of Nigeria. Journal of Agricultural Research Vol. 1(7), pp. 83-87.

Naeem, S.et al., 2018. Role of pollinators in pea (Pisum sativum) yield at Peshawar valley. JournalofEntomologyandZoologyStudies2018;6(2):1280-1282

Otieno, M., Sidhu, C.S., Woodcock, B.A., Wilby, A., 2015. Local and landscape effects on bee functional guilds in pigeon pea crops in Kenya. J. Insect Conserv. https://doi.org/10.1007/s10841-015-9788-Z

Otieno, M., Woodcock, B.A., Wilby, A., Vogiatzakis, I.N., Mauchline, A.L., Gikungu, M.W., Potts, S.G., 2011. Local management and landscape drivers of pollination and biological 
control services in a Kenyan agro-ecosystem. Biol. Conserv. 144, 2424-2431. https://doi.org/10.1016/j.biocon.2011.06.013.

Pando, J., Fohouo, F., Lebel, J., 2011a. Chalicodoma cincta cincta (Hymenoptera: Megachilidae) in Yaoundé (Cameroon). J. Anim. Plant Sci. 11, 1346-1357.

Pando, J.B., Fohouo, F.N.T., Tamesse, J.L., 2011b. Foraging and pollination behaviour of Xylocopa calens Lepeletier (Hymenoptera: Apidae) on Phaseolus coccineus L. (Fabaceae) flowers at Yaounde (Cameroon). Entomol. Res. 41, 185-193. https://doi.org/10.1111/j.1748-5967.2011.00334.X

Pasquet, R.S., Peltier, A., Hufford, M.B., Oudin, E., Saulnier, J., Paul, L., Knudsen, J.T., Herren, H.R., Gepts, P. (2008) Proceedings of the National Academy of Sciences. 105 (36) 13456-13461; DOI: 10.1073/pnas.0806040105

Rodger, J.G., Balkwill, K., Gemmill, B., 2004. African pollination studies: Where are the gaps? Int. J. Trop. Insect Sci. https://doi.org/10.1079/IJT20045

Roubik, D. W. 1995. Pollination of cultivated plants in the tropics, FAO Agricultural Services Bulletin 118.

Stephanie, K.B. Ngakou Albert, N., Fohouo, T. And Fernand Nestor, F. (2015). Pollination and yield attributes of (cowpea) Vigna unguiculata L. Walp. (Fabaceae)as influenced by the foraging activity of Xylocopa olivacea Fabricius (Hymenoptera: Apidae) and inoculation with Rhizobium in Ngaoundere, Cameroon. International Journal of Agronomy and Agricultural Research. 6(2), p. 62-76.

Wousla, E.N., Andargie, M., Pasquet, R.S., Mondon, M., Menez, V., Cochin, C., Paul, L., Pardon, L. and Roubaud, M. (2019) Is bigger better? Apidae (Xylocopinae), megachilidae and cowpea (Vigna unguiculata) pollination. Plant Breeding. https://doi.org/10.1111/pbr.12763. 


\section{Appendix 3b: References of studies on pests of legume crops and associated yield losses in Africa}

Abate, T. and Ampofo, J.K.O. (1996) Insect Pests of Beans in Africa: Their Ecology and Management. Annual Review of Entomology, 41, 45-73. http://dx.doi.org/10.1146/annurev.en.41.010196.000401

Abudulai, M., Salifu, A.B., Opare-Atakora, D et al., (2012) Yield loss at the different growth stages in soybean due to insect pests in Ghana, Archives of Phytopathology and Plant Protection 45(15):1-14 DOI: 10.1080/03235408.2012.706744.

Ali, K., Chichabeylu,M., Abate, T., Tefera, T. and Dawd, M. (2009). Two decades of research on insect pests of grain legumes. In: Tadesse, A.(Ed.)Increasing crop production through improved plant protection-Volume II.pp. 38-84.Plant Protection Society of Ethiopia (PPSE). PPSE and EIAR, Addis Ababa, Ethiopia.

Biddle,J. and Cattlin, A.N. (2007). Pests, Diseases and Disorders of Peas and Beans. London: CRC Press, https://doi.org/10.1201/b15137.

Dialoke SA, Agu CM, Ojiako FO, Onweremadu E, Onyishi GO, Ozor N, Echezona BC, Ofor MO, Ibeawuchi II, Chigbundu IN, Ngwuta AA and Ugwoke FO. 2010. Survey of insect pests on pigeonpea in Nigeria. Journal of SAT Agricultural Research 8.

Dike, M.C. (1997) Effect of insect pests on pod and seed yields of bambara groundnut, Vigna subterranea L. Verde in Nigeria, International Journal of Pest Management, 43:3, 191-192, DOI: $10.1080 / 096708797228663$

Duan, C., Zhu, Z., Ren, G., Wang, X., and Li, D. (2014) Resistance of Faba Bean and Pea Germplasm to Callosobruchus chinensis (Coleoptera: Bruchidae) and Its Relationship With Quality Components, Journal of Economic Entomology. 107(5) 1992-1999, https://doi.org/10.1603/EC14113

Hansen, L.M., Lorentsen, L. and and Boelt, B. (2008) How to reduce the incidence of black bean aphids (Aphis fabae Scop.) attacking organic growing field beans (Vicia faba L.) by growing partially resistant bean varieties and by intercropping field beans with cereals Pages 359-364 | Received 06 Jun 2007, Published online: 27 Oct 2008 https://doi.org/10.1080/09064710701788844

Hartman, G.L., West, E.D. and Herman, T. (2011) Crops that feed the World 2. Soybeanworldwide production, use, and constraints caused by pathogens and pests. Food Security 3(1):5-17, DOI: • 10.1007/s12571-010-0108-x

Karungi, J., Adipala, E., Nampala, P.M., Kyamanywa, S. and Ogenga-Latigo, M.W. (2000) Pest management in cowpea. Part 3. Partitioning yield loss due to cowpea field pests in eastern Uganda. Crop Protection 19, 343-347. 
Latif, A., Malik, S.A., Saeed, S., Iqbal, N., Saeed, Q., Khan, K.A., Ting, C., Ghramh, H.A., 2019. Diversity of pollinators and their role in the pollination biology of chickpea, Cicer arietinum L. (Fabaceae). J. Asia-Pac. Entomol. 22, 597-601.

Minja EM, Shanower SN, Silim SN, Singh L (1999). Evaluation of pigeonpea pod borer and pod fly tolerant lines at Kabete and Kiboko in Kenya. Afr. Crop Sci. J. 7: 71-79.

Mkandawire, C. (2007). Review of Bambara groundnut (Vigna subterranean (L.) Verdc. Production in sub-sahara Africa. Agricultural Journal, 2(4): 465- 470.

Mwanauta, R.W., et al., (2015) Potential of Controlling Common Bean Insect Pests (Bean Stem Maggot(Ophiomyia phaseoli), Ootheca (Ootheca bennigseni) and Aphids (Aphis fabae)) Using Agronomic, Biological and Botanical Practices in Field. Agricultural Sciences, 6, 489-497. http://dx.doi.org/10.4236/as.2015.65048

Ochilo, W.N. and Nyamasyo, G.H. (2011) Pest Status of Bean Stem Maggot (Ophiomyia spp.) and Black Bean Aphid (Aphis fabae) in Taita District, Kenya [Situación de las plagas Del frijol: Gusano del Tallo. Tropical and Subtropical Agro Ecosystems, 13, 91-97.

Ojwang', P.P.O., Melis, R., Songa, J.M., Githiri, M., 2010. Genotypic response of common bean genotypes to natural field populations of bean fly (Ophiomyia phaseoli) under diverse environmental conditions. Field Crops Res. 117, 139-145.

Oyewale, R.O. and Bamaiyi, L. J. 2013. Management of cowpea insect pests. Scholars Academic Journal of Biosciences. 1(5):217-226.

Stevenson, P.C., Dhillon, M.K., Sharma, H.C., El Bhouhssini, M., 2007. Insect pests of lentil and their management. In: Yadav, S.S., McNeil, D., Stevenson, P.C. (Eds.), Lentil, an Ancient Crop for Modern Times. Springer, Dordrecht, The Netherlands, (Ch. 20), pp. 331-348.

Stoddard, F. L., Nicholas, A. H., Rubiales, D., Thomas, J., \& Villegas-Fernandez, A. M. (2010). Integrated pest management in faba bean. Field Crops Research, 115, 308-318. https://doi.org/10.1016/j.fcr.2009.07.002. 


\section{Appendix 3c: References of studies on natural enemies and the pests they control in legume} crops in Africa

Chin, D. and Brown, H. (2010) Biological Control: With Natural Enemies in the Top End. Department of Resources, Darwin.

Javahery, M. (2013) Natural History of Reduvius personatus Linnaeus (Hemiptera: Heteroptera: Reduviidae) in North America. Munis Entomology \& Zoology, 8, 685-703.

Lee, J.C.T. and Landis, D.A. (2001) Natural Enemies in Field Crops: A Guide to Biological Control. Michigan State University Extension, East Lansing.

Mahr, D.L., Ridgway, N.M. and Whitaker, P. (2008) Biological Control of Insects and mites: An Introduction to Beneficial Natural Enemies and Their Use in Pest Management. Extension Biological Control Programs, University of Wisconsin, Madison.

Ndakidemi, B., Mtei, K. and Ndakidemi, P.A., 2016. The Potential of Common Beneficial Insects and Strategies for Maintaining Them in Bean Fields of Sub Saharan Africa. American Journal of Plant Sciences, 7, 425-436. http://dx.doi.org/10.4236/ajps.2016.73036.

Pesticide Action Network (PAN) (2014) Field Guide to Non Chemical Pest Management in Cowpea Production. PAN, Hamburg.

Stewart, S.D., Layton, B. and Catchot, A. (2007) Common Beneficial Arthropods Found in Field Crops. University of Tennessee Extension, Knoxville. http://msucares.com/pubs/publications/e0020.pdf. 